\title{
Risk Premia in International Equity Markets Revisited
}

February 14, 2007

August 5, 2007 (this version)

\section{Stephen J. Brown}

NYU Stern School of Business

New York University

sbrown@stern.nyu.edu

Takato Hiraki*

Institute of Business and Accounting

Kwansei Gakuin University

Kiyoshi Arakawa

SG Asset Management, Tokyo, Japan

kiyoshi.arakawa@sgam.co.jp

and

Saburo Ohno

SG Asset Management, Tokyo, Japan

saburo.ohno@sgam.co.jp

\author{
*Correspondence to: \\ Takato Hiraki \\ Institute of Business (MBA) and Accounting \\ Kwansei Gakuin University \\ 1-1-155 Uegahara \\ Nishinomiya 662-8501 \\ Japan \\ Phone: (+81)798-54-6973 \\ Fax: (+81)798-54-6581 \\ E-mail: thiraki@kwansei.ac.jp
}

We express our appreciation to SG Asset Management, especially Erol Emed and staff members at Quantitative Research Division for their helpful comments and research cooperation and to Morgan Stanley Capital International (MSCI) for its data services on indices used in this research. We also thank Nobuya Takezawa for his helpful comments. 


\title{
Risk Premia in International Equity Markets Revisited
}

\author{
Abstract \\ Recent evidence suggests that global equity markets are becoming more risky. We find that much of the \\ apparent increase in international variance and covariance of returns can be attributed to systematic \\ variations in global risk premia correlated across markets, rather than to any fundamental change in the \\ risk attributes of these markets. This result has interest both for practitioners and for those interested in \\ modeling global asset prices.
}

JEL Classification: G12; G15

Keywords: Risk premia, international asset pricing models, global capital markets, global investments. 
TODAY'S GLOBAL EQUITY MARKETS are characterized by excessively high average return correlations (see, e.g., Goetzmann, Li and Rouwenhorst, 2005). Why have equity market correlations around the world increased to such a high level recently? One can argue that increased return correlations are due to enhanced global economic integration, resulting in diminished diversification opportunities. At the same time that the incentive to diversify internationally has fallen, we observe increased international equity flows as well as a reduction in the home equity bias. ${ }^{1}$ Increased international investment may result from changing economic circumstances characterized by systematic variations in equity risk premia. We find that much of the apparent increase in unconditional global covariances can be attributed to correlated changes in global risk premia. This has important implications not only for equity risk management, but also for developing parsimonious models explaining international asset pricing dynamics.

There are many studies of international asset pricing models. The Intertemporal International Arbitrage Pricing Theory (IIAPT) emphasizes the importance of considering global asset pricing in the context of conditional expectations. Ferson and Harvey (1993), for example, investigate predictability in international equity market returns, focusing on the risk premia, and find that the significant fraction of excess return variation is explained by time variation in global risk premia. Dumas and Solnik (1995) show that a conditional asset pricing model, in which both risk premia and factor loads vary over time, in

\footnotetext{
1 See, for example, Ahearne, Griever and Warnock (2004) for an analysis of U.S. holdings of foreign equities.
} 
a statistical sense outperforms its unconditional counterpart for equity and currency markets of the four largest economies (Germany, U.K., Japan, and the U.S.). They also find that a multiple-factor conditional model outperforms a single-factor conditional model. Choi, Hiraki and Takezawa (1998) show an advantage of conditional APT models over unconditional models in that the former can capture the time-varying risk premium associated with foreign exchange risk in the Tokyo stock market better than the latter. In these studies, the conditioning variables used to predict time-varying risk premia, i.e., first moments, are evaluated but their contribution to unconditional covariances is not seriously considered. More recently, Bekaert, Hodrick and Zhang (2005) attempt to establish a single parsimonious asset pricing model to capture the covariance structure of international equity market returns. Their focus is on the changes of unconditional variance (and covariance) measured over many short periods on a (six-month) rolling basis with the use of a weekly interval. They find that a three-factor APT specification, using factor analysis and mimicking portfolio techniques, best serves their purpose of total variance decomposition; and that the changes in betas contribute most to explain the time behavior of variance within the value-weighted global market portfolio. However, they find neither an upward trend in return correlations, except for the European stock markets, nor the steadily decreasing importance of industry factors relative to country factors in driving global correlations.

By fixing betas and allowing risk premia to vary over time, Brown and Otsuki (1993) find that risk premia in the Pacific-Basin markets for the period 1981-1992 are predictable on the basis of prior 
information available to investors. Their major contribution is to show that factor innovations, factor

loadings and risk premia may be determined simultaneously in a single system of equations. In this

context it is easy to see how much of the increase in international variance and covariance of returns

might be attributed to systematic variations in global risk premia, rather than to any fundamental change

in the risk attributes of these markets. We update this framework to consider the possibility that

idiosyncratic (or total) risk might be a source of priced risk $^{2}$ and allow for an additional residual fixed

income market factor consistent with Bekaert and Grenadier (2001).

We examine the extent to which changing risk premia explain the observed increase in

unconditional international return covariances by decomposing unconditional global market variance into

factor innovation and changing risk premia components ${ }^{3}$. By comparing two sub periods, we find that

changes in risk premia and the common factor innovation process contribute significantly to measured

increases in global covariance risk. This result has important implications for the practice of and the

modeling for global asset management.

We extend this risk decomposition to consider the role of industry factors relative to country

factors by preparing the two sets of global asset classes. This extension again complements the result

${ }^{2}$ Bennet and Sias (2007) argue that limits to arbitrage may make idiosyncratic risk difficult to diversify. This might be especially true of international equity portfolios. Malkiel and Xu (1997) and Goyal and Santa Clara (2003) document that this has a positive relationship with returns in a domestic market context. On the other hand, Ang, Hodrick, Xing and Zhang (2006) and Guo and Savickas (2006) documents a negative relationship at the firm level and the aggregate level, respectively. We speculate that average risk of the U.S. market, (as measured by VIX, provided by the Chicago Board Options Exchange) represents a common source of priced risk as well as a potential state variable useful for predicting changes in global risk premia. It does not include idiosyncratic risk for U.S. domestic investors, but may serve as a proxy for the average total risk of the market portfolio in a diversified global context.

${ }^{3}$ A similar decomposition is found in Bekaert, Hodrick and Zhang (2005). 
from the Bekaert, Hodrick and Zhang (2005) study using a different asset pricing model.

The paper is organized as follows: Section I presents the model structure and specification.

Section II describes the data with correlation analysis. In section III we estimate the model for country index portfolios. We also provide the robustness check for the result. Section IV provides the implications of the results for global asset pricing modeling and investment practices with the total risk decomposition in various ways. We report the comparison between the predicted risk premia and the realized excess return for each of the component assets and also allowing for industry decomposition. Section $\mathrm{V}$ concludes.

\section{The Model}

\section{A. Model Structure}

Based on the IIAPT, returns realized during period $t$ on international assets are described as follows:

$$
R_{t}=E\left(R_{t}\right)+f_{t} B+v_{t},
$$

where $R_{t}$ is a $(1 \mathrm{x} \mathrm{N})$ excess return vector, $f_{\mathrm{t}}$ is a $(1 \mathrm{x} \mathrm{K})$ vector of macroeconomic factors or simply factor innovations, $B$ is a $(\mathrm{K} \times \mathrm{N})$ sensitivity matrix and $v_{\mathrm{t}}$ is a $(1 \times \mathrm{N})$ vector of asset-specific idiosyncratic returns. Returns and factors are realized during the period specified by t. $E\left(\mathrm{R}_{t}\right)$ is the expected excess return formed at the beginning of period t. $\mathrm{N}$ is the number of global asset classes, i.e., country indices or 
global industry indices. The model assumes that factor sensitivity in the matrix is fixed throughout the sample period $(1, \mathrm{~T})$. Absence of any international arbitrage assures

$$
E\left(R_{t}\right)=\lambda_{0 t}+\lambda_{t} B
$$

where $\lambda_{0 \mathrm{t}}=0$ should hold for the risk-free version of the IIAPT and $\lambda_{\mathrm{t}}$ is a $(1 \mathrm{x} \mathrm{K})$ vector of risk premia per unit of systematic risk. The model allows the expected excess return to vary over time. Introducing the predictability or time variation to risk premia, i.e., $\lambda_{t}=X_{t} \alpha$, equation (1) is rewritten as:

$$
R_{t}=X_{t} \alpha B+f_{t} B+v_{t}
$$

where $X_{\mathrm{t}}$ is a $(1 \mathrm{x} \mathrm{M})$ vector of instrumental variables and $\alpha$ is an $(\mathrm{M} \mathrm{x} \mathrm{K})$ matrix of coefficients. More specifically, $X_{\mathrm{t}}$ is a vector of proxy (instrumental) variables of the unknown state variables, measured at the beginning of period t. The $\alpha$ coefficient matrix determines predictable risk premia per unit of systematic risk for the given $X_{\mathrm{t}}$. The first term of equation (3) represents the vector of $\mathrm{N}$ expected excess returns or the risk premia for period $\mathrm{t}$. The first element of $X_{\mathrm{t}}$ is time-invariant unity for all $\mathrm{t}=1, \ldots, \mathrm{T}$.

Non-linear equation (3) is alternatively expressed as:

$$
R_{t}=X_{t} \rho+f_{t} B+v_{t}
$$

where the coefficients of instrument variables $X_{\mathrm{t}}$ are shown as $\rho=\alpha B$, an (M x N) matrix.

For the given $K$ pre-specified macro factors for period $t, y_{\mathrm{t}}$, the factor innovation $f_{\mathrm{t}}$ is expressed as:

$$
f_{t}=y_{t}-Z_{t} \phi
$$


where $\mathrm{Z}_{\mathrm{t}}$ is a set of available information $\left[X_{t}, X_{t-1}, \cdots, X_{t-l}, y_{t-1}, y_{t-2}, \cdots, y_{t-l}\right]$. When maximum lag length $l$ equals zero for $X$ and one for $y, Z_{t}$ is an $(1 \times(\mathrm{M}+\mathrm{K}))$ vector consisting of $X_{\mathrm{t}}$ and one-period lagged values of $y$. The $f_{\mathrm{t}}$ vector is conveniently derived through a vector auto-regressive (VAR) analysis of the following form:

$$
y_{t}=Z_{t} \phi+f_{t}
$$

where $\phi$ is an $((\mathrm{M}+l \mathrm{~K}) \mathrm{x} \mathrm{K})$ matrix of coefficients.

The empirical APT literature suggests that the $(\mathrm{K}+1)^{\text {th }}$ factor can be the residual market factor orthogonalized to all other factor innovations. ${ }^{4}$ The market factor in this case typically implies the return on the global equity market. We add to the existing set of factors and the residual equity market factor one additional residual market factor taken from the international bond market. This treatment of the capital market is consistent with the result obtained by Bekaert and Grenadier (2001). Further, Chordia, Sarka and Subramanyam (2005) find that stock and bond markets are possibly integrated through common monetary forces and fund flows, ${ }^{5}$ which further justifies consideration of a residual bond market factor. Whether these orthogonalized factors are priced is of course an empirical matter.

We simultaneously estimate the asset pricing parameters in equations (3), (4) and (6) for component asset, market returns and factor innovations, respectively. ${ }^{6}$ This system of equations is

\footnotetext{
${ }^{4}$ It is usually taken from the equity market. The idea is initially suggested by McElroy and Burmeister (1988). The importance and application of this factor are discussed in Elton and Gruber (1995).

${ }^{5}$ However, their main focus is on market liquidity in a domestic context.

${ }^{6}$ The innovation processes of equity and bond market returns in detail are shown by (A1) and (A2) in
} 
simultaneously estimated through Iterated Non-linear Seemingly Unrelated Regression (ITNLSUR) as shown in Appendix A. This methodology is proved to be most efficient in an information context (Brown and Otsuki, 1993). We select the best model in specification primarily based on Akaike Information Criterion (AIC) provided by Akaike (1973) out of various combinations of factors and instrumental variables.

\section{Data}

We analyze returns on global asset classes from the viewpoint of U.S. investors who convert local currency returns into U.S. dollar returns. ${ }^{7}$ Morgan Stanley Capital International (MSCI) provides

the MSCI World (MSCI_WRLD) Index, which is the value-weighted global market index consisting of the 21-national indices or, alternatively, the 23 -industry indices (see panels B and C of Table I) ${ }^{8}$. In the model, the world equity market returns are reduced to the residual equity market factor series as shown in equation (A1). The returns on each country (or industry) index are computed from the corresponding value-weighted national market (or industry) index series constructed by MSCI. All U.S. dollar returns are measured on a monthly basis and are converted into excess returns by subtracting the one-month U.S.

Appendix A, respectively,

7 If the equilibrium asset pricing model holds in this setting, the pricing of risk factors should be at least approximately assured in a different currency setting, such as the Japanese yen, in the same integrated pricing system.

${ }^{8}$ We exclude Portugal, Greece, and Malaysia, all of which are included in the MSCI_WRLD since November 1998. The 23 industry classes used in this study exclude the Semiconductor Industry, included there since May 2003. These exclude are not consistently available throughout our sample period from March (or April) 1994 to December 2004. 
Treasury-bill yield. Thus, the excess returns constitute realized risk premia from the viewpoint of globally investing U.S. investors. Because of the possible integration between global equity and bond markets, we also consider the world bond market index and two bond market composite indices (from the U.S. and Japan) to alternatively specify our model. ${ }^{9}$ All asset prices are sampled from March 1994 to December 2004 for the rates of return for the test period from April 1994 to December 2004.

Panel A of Table I lists both factors and instruments considered in this study. Brown and Otsuki (1993) use unexpected foreign exchange rates of changes (yen/dollar rates or alternative trade-weighted rates), unexpected changes in Euro (then U.K.) short interest rates, unexpected U.S. small firm returns, and the residual equity market factor. The small equity return factor is similar to the one of the Fama-French three factors (Fama and French, 1992 and 1993). Overall, with the residual market factor, their APT factors represent global economic forces as well as balanced segment factors (i.e., the U.S., Europe, and Japan) of the global markets, all of which are on our list.

We list three out of the four yield/inflation measures used by Brown and Otsuki (1993) in this category: two term-structure variables from the U.S. and Japan in addition to U.S. inflation rates. These are traditionally supported in U.S. domestic APT tests (for example, Chen, Roll, and Ross, 1986). We do not list dividend yields although the literature (Bekaert and Hodrick, 1992, Dumas and Solnik, 1995 and

\footnotetext{
${ }^{9}$ Citigroup World Government Bond Index (WGBI), bond, is used as the entire world bond market performance index. The U.S. and Japanese government bond market indices are the two most important composites of the WGBI.
} 
Choi, Hiraki and Takezawa, 1998) demonstrates the ability of this variable to predict future returns. We

try to be conservative in predicting risk premia without much depending on the predictors using equity

prices.

We investigate a few unique proxies for investor sentiment such as VIX and FLOW. ${ }^{10}$ VIX can

be a manifestation of investors' diverging opinions on the future movement of (U.S. and global) equity

markets, thus possibly representing broad investor sentiment ${ }^{11}$. A similar interpretation is possible for

FLOW involving international equity transactions though much representing Japanese equity market

perspectives. The changes in these variables may predict changes in risk premia formed by global

investors. At the same time, the exposure to the changes in investor sentiment as a factor may be priced

(see Barberis and Shleifer, 2001). Thus, each of these two variables (or their variants) is investigated as a

factor as well as an instrument variable in our model specification.

The sample period of this study, April 1994 through December 2004, corresponds to the second

peak of the U-shaped average global equity market correlation over the past century, with the first peak

during the 1920s according to Goetzmann, Li and Rouwenhorst (2005). Global capital markets today

possibly show the highest average correlation in history. It is evident that the average correlation during

${ }^{10}$ VIX corresponds to CBOE's implied volatility index on S\&P100 (OEX) options. FLOW is a normalized equity flow variable based on the (1 x 4) vector of percentage net flows for individuals, foreigners, domestic institutions and securities firms on the Tokyo Stock Exchange. When these are investigated as factors, the rate of changes over period $t$ is used.

11 Preliminary OLS regression analyses suggest that the monthly growth of the VIX Index is related to contemporary and future global equity returns, and thus that it is worthwhile to reinvestigate it in our system of simultaneous equations after appropriate orthogonalization. The result of more detailed analysis on VIX is as a factor or a instrument is available upon request. 
the sample period of this study is higher than that during the sample period used by Brown and Otsuki (1993), mainly the 1980s. Table II shows the correlation matrix of monthly (raw) country index returns in U.S. dollars for each of the two approximately evenly divided sub-periods. Even within our short sample period, there may be a significant upward shift in general correlations between the first and the second sub-period $^{12}$. Global portfolio investment may be recently less attractive for global investors to reduce risk. This view should be supported unless expected return predictability across the time and assets is assured.

\section{Empirical Estimation of the Model}

We investigate various model specifications using the variables listed in Table I. Based on the AIC procedure, we select one benchmark specification for our subsequent analysis of risk premia. ${ }^{13}$ The model specification identified as most parsimonious includes the factors for energy price (oil), U.S. small-firm stock (sus), Euro-global interest rate (teu), yen/dollar currency (ljap), and the two residual market factors ( $m$ and $\mathrm{bm}$ ); and the Japanese yield spread (ysjap), U.S. yield spread (ysus), Euro yield spread (yseu) and VIX as instrumental variables. In addition, the model includes the two kinds of residual market factors. These carefully selected factors and instruments might warrant for us to adequately

\footnotetext{
12 Though the results are not shown, we observe no such obvious shift in correlations over time for the industry index returns.

13 The AIC result is available upon request.
} 
predict risk premia and capture co-movements among international stock markets. The estimation results below are based on this benchmark specification of model.

\section{A. Simultaneous Estimation of the Asset pricing Parameters}

The inclusion of VIX as an instrumental variable and the residual bond market as a factor makes our empirical model different from Brown and Otsuki's (1993). As the results in Table III shows, these two variables contribute to improve the model estimate significantly. VIX is indeed more significant than any other instruments in predicting risk premia (panel B, Table III). The joint risk premia determination by VIX across the six factors is significant in terms of the chi-square statistics at the one percent level. The risk premium associated with the residual bond market factor is highly significant in both $\mathrm{t}$ and chi-square statistics (panel $\mathrm{B}$ ). This factor is almost as important as the residual equity market factor in generating returns across the country indices (panel C).

The role played by the residual equity market factor is somewhat different in this study from Brown and Otsuki (1993). The chi-square test result for the null hypothesis with respect to the residual equity market factor is rejected only at the five percent level (not at the one percent level). The statistical significance is also lower for this factor than for the other factors in our study. This is not due to the effect of the newly added residual bond market factor, since a similar result (not shown) is obtained without it. The estimation result in panel $\mathrm{C}$ shows that the global equity market excess return variation explained by 
the variation of the four macroeconomic factors and risk premia is limited to about $10 \%$ in terms of the adjusted $\mathrm{R}^{2}$ statistic, which is considerably lower than that reported by Brown and Otsuki (1993) and others. The reduced role of the global equity market returns happens in spite of the fact that the residual equity market factors account for more than $90 \%$ of the variation in global equity market (MSCI_WRLD) returns.

\section{B. Robustness of the Model}

The benchmark specification is now fitted with the use of a few different asset classes. Panel A of Table IV shows the determination of risk premia for each factor by the four instrumental variables in terms of $\mathrm{t}$ and chi-square statistics with the 23 global industry indices (see panel $\mathrm{C}$ of Table I). The risk premia associated with all factors but the U.S. small stock return factor (sus) remain significant in terms of chi-square statistics at one percent level. The null hypothesis that $\alpha$ coefficients associated with the U.S. small stock return factor across different instruments are all zero is not rejected at any conventional level of statistical significance. On the other hand, the chi-square test result for the column under $m$ (residual equity market factor) becomes more significant at the one percent level (not the five percent level) than in panel B of Table III. Except for the sus factor, all factors and instruments are even more significant.

Overall, the model is robust with the use of global industry indices instead of country indices.

Panel B of Table IV shows the estimation result on risk premia prediction with the benchmark 
model applied to the nine Pacific-Basin country indices including Japan, the U.S., Hong Kong, Singapore,

Australia, New Zealand, the Philippines, Taiwan and Korea. The overall result is insignificant both in the $\mathrm{t}$ and chi-square statistics. Almost all $\alpha$ estimates are statistically insignificant, while the chi-square joint test of $\alpha$ coefficients shows that sus, teu, both residual market factors, $m$ and $\mathrm{bm}$ (residual bond market factor), and the one instrument, ysjap, are not significant at any conventional level. Even with the U.S. and Japan included, this part of the world equity market does not adequately reward investors for systematic risk estimated using data from the sub-system of the global capital market. The formation of time-varying risk premia for this region would require the action of system additionally including European equity markets. ${ }^{14}$

For additional robustness checking, we use two different sets of asset classes assuming that global markets are integrated between equities and bonds. We add the two bond market indices from the U.S. and Japan, first, to the existing 21 equity country indices and, second, to the existing 23 global industry indices. Adding bond asst classes to equity classes is consistent with what Bekaert and Grenadier (2001), especially, with term structure measures from the U.S., Euro and Japan included in the model as instruments. It is confirmed that the first case of extending asset classes somewhat changes the validity of the model (panel C). The determination of time-varying risk premia is reduced for the ljap factor from highly significant to insignificant in terms of chi-square statistics. All other chi-square statistics remain

14 The same was confirmed using all yen-based excess returns with and without the U.S. The pricing result in this region is not consistent with the segmented-market (i.e., "yen-zone") hypothesis but is consistent with the globally integrated-market hypothesis. 
significant at the one percent level. The result of risk premia determination in the second case is shown in panel D. Interestingly, the result in panel D shows all chi-square statistics are highly significant and the overall result is even more significant than that in panel A and approximately comparable with that in panel A of Table III. The global capital market seems integrated between equities and bonds depending on the classification of equity assets.

The model overall works reasonably well as long as main components of the MSCI_WRLD are included in the system, and there would be a marginal increase in the reliability of the estimated risk premia with more assets from the fixed income class, added to the industry indices. The benchmark model we have established is in general robust with differently defined international asset classes in the system.

\section{Implications}

\section{A. Implications for Increased Global Market Correlations}

Based on equation (1), we first decompose the unconditional variance-covariance matrix of asset class excess returns into the four components related to risk premia, common factor innovations, residuals, and residual covariance (with factor innovations), respectively, as follows: ${ }^{15}$

${ }^{15}$ See Appendix B for the derivation in detail. 


$$
\begin{aligned}
\operatorname{Var}\left(R_{t}^{\prime}\right) & =\left[2 \operatorname{Cov}\left(R_{t}^{\prime}, E\left(R_{t}^{\prime}\right)\right)-\operatorname{Var}\left(E\left(R_{t}^{\prime}\right)\right)\right] \\
& +B^{\prime} \operatorname{Var}\left(f_{t}^{\prime}{ }_{t}\right) B \\
& +\operatorname{Var}\left(v_{t}^{\prime}\right) \\
& +2 B^{\prime} \operatorname{Cov}\left(f_{t}^{\prime}, v_{t}^{\prime}\right) .
\end{aligned}
$$

Since each matrix is not very obvious in this section, we use the prime (') in equation (7) to indicate the transpose of a corresponding vector or matrix. $R_{t}$ is a $(1 \mathrm{x} \mathrm{N})$ excess return vector; $f_{\mathrm{t}}$ is a $(1 \mathrm{x}(\mathrm{K}+2))$ vector of $\mathrm{K}$ factor innovations and two residual market factors; $B$ is a $((\mathrm{K}+2) \times \mathrm{N})$ sensitivity matrix; and $v_{\mathrm{t}}$ is a $(1 \mathrm{x} \mathrm{N})$ vector of asset-specific idiosyncratic returns. Unconditional variance and covariance are computed for the time period $t \in(1, T)$. Notice that $E\left(R_{t}^{\prime}\right)$ is not constant, but it varies in time series. The expected excess returns can be correlated in unconditional measures since investors use common information, i.e., common instruments, over time. We aggregate the total variances of realized excess returns on the left-hand side, and each of the four variance-covariance matrix terms on the right-hand side, of equation (7) over the 21 country indices. In aggregation, we do not use any portfolio weight since our interest is in a general shift of global correlations shown in Table $\mathrm{II}^{16}$. The first risk component in equation (7) is termed the risk premia-caused. The second component represents factor innovation-caused variance and covariance, aggregated over the 21 country indices. The third component is the residual volatility, aggregated. The fourth component represents the volatility caused by factor-residual covariance, aggregated.

If we assume that each time-varying risk premium and its innovation are orthogonal, the risk

\footnotetext{
${ }^{16}$ This implicitly assumes an equally-weighted global market portfolio with 1.0 weight to each index.
} 
premia component in equation (7) converges to $\operatorname{Var}\left(E\left(R_{t}^{\prime}\right)\right)$ due to the property of $\operatorname{Cov}\left(R_{t}^{\prime}, E\left(R_{t}^{\prime}\right)\right)=\operatorname{Var}\left(E\left(R_{t}^{\prime}\right)\right)$. This implies that $2 \operatorname{Cov}\left(R_{t}^{\prime}, E\left(R_{t}^{\prime}\right)\right)$ is twice as large as $\operatorname{Var}\left(E\left(R_{t}^{\prime}\right)\right)$. We subsequently show the comparison between $2 \operatorname{Cov}\left(R_{t}^{\prime}, E\left(R_{t}^{\prime}\right)\right)-\operatorname{Var}\left(E\left(R_{t}^{\prime}\right)\right)$ and $\operatorname{Var}\left(E\left(R_{t}^{\prime}\right)\right)$ to ascertain the empirical validity of our model with respect to the usual orthogonality assumption between risk premia and their innovations. The errors associated with violating the assumption are indeed small in our result as shown subsequently.

Each of the four terms on the right-hand side of equation (7) is further decomposed into diagonal and off-diagonal components. As observed in Table II, global market correlations shift over time.

This shit is contributed by changes in these off-diagonal components. Our model fixes betas of assets for each sample period. The betas differ between the two sub-samples. Keeping this in mind, we further decompose each component of the total risk in equation (7) into diagonal and off-diagonal sub-components. The decomposition of the first risk component caused by risk premia is expressed as:

$$
\begin{aligned}
{\left[2 \operatorname{Cov}\left(R_{t}^{\prime}, E\left(R_{t}^{\prime}\right)\right)-\operatorname{Var}\left(E\left(R_{t}^{\prime}\right)\right)\right] } \\
=\left[2 \sum_{j=i=1}^{N} \operatorname{Cov}\left(R_{i t}^{\prime}, E\left(R_{j t}^{\prime}\right)\right)-\sum_{j=i=1}^{N} \operatorname{Cov}\left(E\left(R_{i t}^{\prime}\right), E\left(R_{j t}^{\prime}\right)\right)\right] \\
+\left[2 \sum_{i=1}^{N} \sum_{\substack{j=1 \\
i \neq j}}^{N} \operatorname{Cov}\left(R_{i t}^{\prime}, E\left(R_{j t}^{\prime}\right)\right)-\sum_{i=1}^{N} \sum_{\substack{j=1 \\
i \neq j}}^{N} \operatorname{Cov}\left(E\left(R_{i t}^{\prime}\right), E\left(R_{j t}^{\prime}\right)\right)\right] .
\end{aligned}
$$

The first (second) solid parenthesized term of the right-hand side of equation (8) corresponds to the diagonal (off-diagonal) component of the risk premia-caused risk. The first term of the diagonal or the off-diagonal component is twice as large as the second term under the assumption of uncorrelated risk 
premia with their corresponding innovations. The net off-diagonal effect in equation (8) shows the degree of global market co-movement measured with respect to risk premia formation. As this measure increases, the global market correlation (or integration) increases with other effects kept constant. The off-diagonal elements also importantly contribute to the risk as variance.

The second component of the total risk in equation (7) is similarly decomposed into diagonal and off-diagonal sub-components as follows:

$$
B^{\prime} \operatorname{Var}\left(f_{t}^{\prime}\right) B=\sum_{i=1}^{N} B_{i}^{2} \operatorname{Var}\left(f_{t}^{\prime}\right)+\sum_{i=1}^{N} \sum_{\substack{j=1 \\ i \neq j}}^{N} B_{i} B_{j} \operatorname{Var}\left(f_{t}^{\prime}\right)
$$

Since we fix betas for each test period, the decomposition of the factor innovation component of risk has a lot simpler structure. These betas transmit factor innovation volatilities to global market covariance and variance.

The third and fourth terms in equation (7) are also similarly decomposed into diagonal and off-diagonal elements.

Throughout our decomposition analysis, we do not mean that the realized (or unconditional) covariance risk caused by time-varying risk premia be the concern of decision-making investors. Investors should measure risk on a conditional base, i.e., on the instrument variables in our case. Nevertheless, we believe that the decomposed unconditional measures of risk still provide investors with useful information on the market performance of forming risk premia in relation to realized excess returns and their volatilities. 
Table V shows the results of various risk decompositions of total excess return volatility using the 21 country indices. First, we observe a substantial increase in the global excess return variance from 0.706 during the first sub-period to 1.037 during the second sub-period. The biggest contribution to this increase is from factor innovations and the second from time-varying risk premia. The contribution of factor innovations increases substantially from 0.493 to 0.834 in magnitude and from $69.72 \%$ to $80.36 \%$ in percentage over the sub-periods. In the meantime, the contribution of risk premia increases from 0.007 to 0.172 in magnitude and from $0.95 \%$ to $16.60 \%$ in percentage, respectively, over the same sub-periods. Changing risk premia are notably more important than factor innovations, $15.65 \%$ vs. $10.64 \%$, in explaining the percent increase in overall market volatilities.

As global equity markets become more volatile and more correlated, risk premia increases their relative importance to factor innovations in contributing to global market co-variations or volatilities. The contribution of the last two risk components to the increase of total global market risk is either negative or negligibly small.

Then, it is interesting to relate the observed increase in the propensity of correlations to the change in global market co-movement focusing on the different contribution between risk premia and factor innovations as main drivers. Our decomposition of risk is more similar to Ferson and Harvey (1993) with time-varying risk premia. Table V contains the result on this decomposition. The same Table also contains the decomposition of each risk component aggregated over the nine Euro member countries 
and the rest of the global market in order to complement the result of Bekaert, Hodrick and Zhang (2005)

using a different factor model for the same purpose.

There are three major results with the further risk decomposition. First, the substantial increase in the risk premia-caused part of total variance is mostly contributed by the increase in (off-diagonal) covariance of risk premia. The off-diagonal percentage (or magnitude) contribution of time-varying risk premia increases from $0.23 \%$ (or 0.002 ) during the first sub-period to $15.42 \%$ (or 0.160 ) during the second sub-period while the diagonal contribution of risk premia to the change is negligible. The global equity market becomes more correlated with respect to the contribution made by time-varying risk premia.

Second, the total variances also increases, caused by factor innovations, from $0.493(69.76 \%)$ during the first sub-period to $0.834(80.36 \%)$ during the second sub-period. This substantial change is not by their diagonal contribution, but by their off-diagonal covariance contribution. The off-diagonal contribution significantly increases from 0.460 (or $65.16 \%$ ) to 0.787 (or $75.73 \%$ ) while the corresponding diagonal contribution is relatively small. This evidence also indicates enhanced global market linkage in covariance caused by factor innovations.

Third, the total variance increases in magnitude from 0.144 to 0.251 for the Euro members and from 0.260 to 0.300 for the non-Euro members, respectively. In percentage, however, the pattern is somewhat different: the total variance contributed by the Euro members (non-Euro members) increases 
(decreases) from $20.38 \%(36.89 \%)$ to $24.22 \%(28.90 \%)$. The third column, titled "Cross", of each sub-panel is to compare the covariance risk contribution between the Euro and the non-Euro member markets. The Euro market contribution to the global market risk though this covariance channel increases from 0.302 (or $42.73 \%$ ) during the first sub-period to 0.486 (or $46.88 \%$ ) during the second sub-period. The change in risk premia contribution to the total risk increase is 0.026 (or $2.02 \%=3.54 \%$ $-1.52 \%$ ), 0.045 (or $4.00 \%$ ) and 0.095 (or 9.62\%) for the Euro, the non-Euro and the Cross categories, respectively. The change in factor innovation contribution to the total risk increase is 0.124 (or $8.63 \%$ ), 0.031 (or $-5.80 \%$ ) and 0.189 (or $7.77 \%$ ) for the Euro, the non-Euro and the Cross categories, respectively. Both in risk premia and factor innovation, the Euro and Cross jointly contribute to the increase in the total global market risk. The non-Euro member market contribution is relatively small or even negative. The overall result on the role of Europe is consistent with the viewpoint that unified Europe is a source of the increased average correlation for the entire global market. It complements Bekaert, Hodrick and Zhang's (2005) study, which obtains some evidence for the increasing trend in correlations among European (especially Euro-member) markets.

Table $\mathrm{V}$ shows that changing risk premia are a major factor explaining the apparent increase in unconditional risk. Total volatility and co-variation jointly increase over time caused by changes in global risk premia captured by our conditioning variables. The result means that these conditioning variables not only predict risk premia but also explain why global markets appear to be increasingly 
correlated.

This result extends to the case where we break down results by industry. Roll (1992) argues

that industrial composition is an important factor explaining the correlation structure observed among

the equity market indices of developed economies. Heston and Rouwenhorst (1994) among others, on

the other hand, find that the country-specific factors dominate the industry factors in determining global

market correlations. There has been some debate on the trend of the relative importance of industry and

country factors. ${ }^{17}$ As the relative importance of the industry factors to the country factors increases, the

effectiveness of global diversification diminishes. ${ }^{18}$ Table VI shows the decomposition of total variance

aggregated over the 23 industries. This decomposition is compared with that of Table $\mathrm{V}$ to analyze the

trend on the relative importance of the industry factors to country factors.

As before, we find in Table VI that total variance increases from the first sub-period to the

second. While time varying risk premia and changes in the factor innovation process almost equally

contribute to this increase in magnitude, the largest component of the percent increase comes from

changes in risk premia. The contribution of risk premia increases in magnitude (from 0.011 to 0.101 ) and

17 Cavaglia, Brightman and Aked (2000) document a decreasing relative importance of the country factors to industry factors, which has an important implication for international investment. Bekaert, Hodrick and Zhang (2005) recently obtain the result in which the increasing relative importance of the industry factors to country factors in Cavaglia, Brightman and Aked (2000) does not appear as a stable, long-run trend.

18 The relative importance of the industry factors to country factors in this paper is measured in the ratio of each off-diagonal covariance contribution with the use of country indices to that with the use of industry indices. The ratio greater than 1.0 means the dominance of the industry factors. We observe the change in this ratio for trend. 
in percentage (from $1.68 \%$ to $11.39 \%$ ) with the use of industry indices. The off-diagonal contribution dominates in this case.

The off-diagonal contribution of risk premia to the total risk increases from 0.002 (or $0.23 \%$ ) to 0.160 (or $15.42 \%$ ) for the 21 country indices (Table V) while the corresponding change is smaller from 0.009 (or $1.35 \%$ ) to 0.091 (or $10.29 \%$ ) for the 23 industry indices (Table VI). The covariance ratio changes from $.22(=0.002 / 0.009)$ to 1.76 . This result suggests that the relative importance of the industry factors has increased over the sub periods. The off-diagonal contribution of factor innovations to the covariance risk changes from 0.460 (or $65.16 \%$ ) to 0.786 (or $73.74 \%$ ) for the 21 country indices and from 0.598 (or $91.81 \%$ ) to 0.701 (or $78.98 \%$ ) for the 23 industry indices, respectively. The covariance ratio changes from 0.77 to 1.12 . The relative importance of the industry factors to country factors has increased with respect to factor innovations. The result may suggest that considering industry diversification in a global portfolio choice may be worthwhile along the trend. Our decomposition of off-diagonal risk might provide some additional insight to the current deviate on the relative importance between country factors and industry factors in deriving global correlations.

\section{B. Implications for Practice}

Figure 1 depicts the average relationship between the expected excess returns and the realized excess returns, both annualized. The risk premia are computed for each of the 21 country indices and the 
two global market indices for equity and bond markets. Out of these 23 indices, there are fourteen (or nine) markets in which the model overstates (or understates) the risk premia. The lowest average risk premium of $-4.30 \%$ is predicted for the Japanese market while its average excess return realized is $-4.01 \%$. The result captures rather well an unusual characteristic of the Tokyo market during the 1990s and the early 2000 s. For the U.S. market, the difference is negative at $-0.32 \%$. The largest positive deviation is observed for the Hong Kong market at $+0.50 \%$ while the New Zealand market shows the largest negative deviation at $-1.36 \%$. The model predicts risk premia fairly accurately.

Table VII statistically shows the same result as in Figure 1. The statistics are based on the 129 monthly observations of risk premia through the benchmark model. The mean difference between the predicted and the realized risk premia is not statistically significant for all of the indices. The model demonstrates its high power to predict risk premia that vary over time across the markets. The reliability of the model is also confirmed through its almost perfect prediction of the excess returns on the indices of the world equity and bond markets. Our result on risk premia prediction has important implications, especially, for active global portfolio investment practices.

\section{Conclusion}

We extend an intertemporal international APT (IIAPT) models, proposed by Brown and Otsuki (1993), to analyze risk premia in global equity markets. Based on data for the period from April 1994 to 
December 2004, this model shows that risk premia contribute more than factor innovations to the observed increase in global market total risk. Further breaking down each risk component into off-diagonal and diagonal sub-components reveals that risk premia are more important than factor innovations for increased global market co-movement over time. We also confirm that Euro member markets mainly drive this part of increased global market correlations, which complements Bekaert, Hodrick and Zhang's (2005) result. The same total risk decomposition analysis applied to the 23 industry indices leads to similar results to the 21-country index case: an increased relative importance of risk premia to factor innovations for the increase in global market variance and co-variation.

We interpret the overall result as indicating that time-variation of risk premia is the cause rather than the consequence of the recently increased volatility in the global market. The time-variation of risk premia is the important cause of the apparent increase in global market correlation. Properly managed, international equity investment still provides significant diversification opportunities. 


\section{Appendix}

\section{A. Iterated Non-linear Seemingly Unrelated Regression (ITNLSUR) Procedure}

The $(\mathrm{K}+1)^{\text {th }}$ factor innovation process in our model is specified as follows:

$$
R_{m t}=X_{t} \rho_{m}+f_{t} B_{m}+f_{m t}
$$

where $R_{\mathrm{m}}$ is a scalar representing global equity market excess return for period $\mathrm{t}$, and $\rho_{\mathrm{m}}$ is an (M x 1)

sensitivity vector to $X_{\mathrm{t}} . \quad f_{\mathrm{mt}}$ is the residual equity market factor for period t, while $B_{\mathrm{m}}$ is a $(1 \mathrm{x} \mathrm{K})$ vector

of factor sensitivities. Notice that $f_{\mathrm{mt}}$ is orthogonal to $f_{\mathrm{t}}$ as well as to $X_{\mathrm{t}}$. The $(\mathrm{K}+2)^{\text {th }}$ factor innovation process is similarly specified as:

$$
R_{b m t}=X_{t} \rho_{b m}+f_{t} B_{b m}+f_{m t} b_{b m}+f_{b m t},
$$

where $f_{\mathrm{bmt}}$ is the residual bond market factor for period t. With these two residual market factors, the return-generating part of the model for $\mathrm{N}$ assets is written as:

$$
R_{t}=X_{t}\left[\alpha B+\alpha_{m} \beta_{m}+\alpha_{b m} \beta_{b m}\right]+f_{t} B+f_{m t} \beta_{m}+f_{b m t} \beta_{b m}+v_{t}
$$

Using the monthly time-series cross-sectional data, we estimate parameters in (6), (A1), (A2), and (A3) simultaneously. More specifically, we estimate the parameters of $\alpha, B, \alpha_{m}, \beta_{m}, \alpha_{b m}, \beta_{b m}, \phi_{m} \rho_{m}, \rho_{b m}, B_{m}, B_{b m}$ and $b_{b m}$. The entire system consists of $[(\mathrm{K}+2)+\mathrm{N}]$ equations, and the last $\mathrm{N}$ equations are non-linear in nature as shown in equation (A3).

McElroy and Burmeister $(1988,1991)$ develop ITNLSUR which simultaneously estimates factor sensitivities and risk premia in the APT. Based on Brown and Otsuki (1993), we simultaneously estimates 
all factor innovations, factor sensitivities and risk premia. The objective function for our ITNLSUR is

expressed as:

$$
\begin{aligned}
& \text { Min. } \eta^{\prime}(\theta)\left(S^{-1} \otimes I_{T}\right) \eta(\theta) / T, \\
& \theta
\end{aligned}
$$

where $\theta$ is a set of parameters to be estimated; $S$ is the estimate of the $(\mathrm{g} \times \mathrm{g})$ cross-equation (variance-)covariance matrix of residuals, $\Sigma ; \mathrm{I}_{\mathrm{T}}$ is a $(\mathrm{T} \times \mathrm{T})$ unit matrix; and $\otimes$ shows a Kronecker product. The $((\mathrm{g} \times \mathrm{T}) \times 1)$ residual vector in our ITNLSUR is formally expressed as:

$$
\eta=\left[\begin{array}{ccc}
\left(\hat{f}_{1,1}, \hat{f}_{1,2},\right. & \cdots & \left., \hat{f}_{1, T}\right)^{\prime} \\
\left(\hat{f}_{K, 1}, \hat{f}_{K, 2}, \cdots\right. & \left., \hat{f}_{K, T}\right)^{\prime} \\
\left(\hat{f}_{m, 1}, \hat{f}_{m, 2}, \cdots\right. & \left., \hat{f}_{m, T}\right)^{\prime} \\
\left(\hat{f}_{b m, 1}, \hat{f}_{b m, 2}, \cdots, \hat{f}_{b m, T}\right)^{\prime} \\
\left(\hat{v}_{1,1}, \hat{v}_{1,2}, \cdots\right. & \left., \hat{v}_{1, T}\right)^{\prime} \\
& \cdots & \\
\left(\hat{v}_{N, 1}, \hat{v}_{N, 2}, \cdots\right. & \left., \hat{v}_{N, T}\right)^{\prime}
\end{array}\right]
$$

where $g=(\mathrm{K}+2+\mathrm{N})$. 


\section{B. Total Variance Decomposition:}

We assume that expected returns are formed at the beginning of the current period by using information then available. As a result, these expected returns correlate in cross-section and take non-zero variance in time series. The variance of realized risk premia is decomposed based on equation (1) which is now rewritten as:

$$
R_{t}^{\prime}-E\left(R_{t}^{\prime}\right)=B^{\prime} f_{t}^{\prime}+v_{t}^{\prime}
$$

Taking a variance form on both sides, we obtain

$$
\begin{gathered}
\operatorname{Var}\left(R_{t}^{\prime}-E\left(R_{t}^{\prime}\right)\right)=\operatorname{Var}\left(R_{t}^{\prime}\right)+\operatorname{Var}\left(E\left(R_{t}^{\prime}\right)\right)-2 \operatorname{Cov}\left(R_{t}^{\prime}, E\left(R_{t}^{\prime}\right)\right),(\mathrm{A} 7) \\
\operatorname{Var}\left(B^{\prime} f_{t}^{\prime}+v_{t}^{\prime}\right)=B^{\prime} \operatorname{Var}\left(f_{t}^{\prime}\right) B+\operatorname{Var}\left(v_{t}^{\prime}\right)+2 B^{\prime} \operatorname{Cov}\left(f_{t}^{\prime}, v_{t}^{\prime}\right) .
\end{gathered}
$$

$(\mathrm{A} 7)=(\mathrm{A} 8)$ leads to:

$$
\begin{aligned}
& \operatorname{Var}\left(R_{t}^{\prime}\right)=\left[2 \operatorname{Cov}\left(R_{t}^{\prime}, E\left(R_{t}^{\prime}\right)\right)-\operatorname{Var}\left(E_{t-1}\left(R_{t}^{\prime}\right)\right)\right]+\left[B^{\prime} \operatorname{Var}\left(f^{\prime}\right) B\right] \\
& \quad+\left[\operatorname{Var}\left(v_{t}^{\prime}\right)\right]+\left[2 B^{\prime} \operatorname{Cov}\left(f_{t}^{\prime}, v_{t}^{\prime}\right)\right] .
\end{aligned}
$$

If each risk premium and its innovation are orthogonal, $2 \operatorname{Cov}\left(R_{t}^{\prime}, E\left(R_{t}^{\prime}\right)\right)$ is twice as large as $\operatorname{Var}\left(E\left(R_{t}^{\prime}\right)\right)$. Then, the total risk of the global market is expressed as:

$$
\operatorname{Var}\left(R_{t}^{\prime}\right)=\left[\operatorname{Var}\left(E_{t-1}\left(R_{t}^{\prime}\right)\right)\right]+\left[B^{\prime} \operatorname{Var}\left(f^{\prime}\right) B\right]+\left[\operatorname{Var}\left(v_{t}^{\prime}\right)\right]+\left[2 B^{\prime} \operatorname{Cov}\left(f_{t}^{\prime}, v_{t}^{\prime}\right)\right]
$$




\section{REFERENCES}

Ahearne, Alan G., William L. Griever, and Francis E. Warnock, 2004, "Information costs and home bias: An analysis of US holding of foreign equities," Journal of International Economics 62, 313-336.

Akaike, Hirotsugu, 1973, "Information theory and an extension of the maximum likelihood principle," Proceedings, 2nd International Symposium on Information Theory (B. N. Petrov and F. Csaki, eds.), Academiai Kiado, Budapest, 267-281.

Ang, Andrew, Robert J. Hodrick, Yuhang Xing and Xiaonyan Zhang, 2006, "The cross section of volatility and expected returns," Journal of Finance 61, 259-299.

Barberis, Nicholas, and Andrei Shleifer, 2001, "Style investing," Working Paper, University of Chicago and Harvard University.

Bekaert, Geert, and Campbell Harvey, 1995, “Time-varying world market integration," Journal of Finance 50, 403-444.

Bekaert, Geert, and Steven R. Grenadier, 2001, "Stock and bond pricing in an affine economy," Columbia Business School Working Paper.

Bekaert, Geert, Robert J. Hodrick, and Xiaoyan Zhang, 2005, "International stock return comovements," National Bureau of Economic Research Working Paper 11906. 
Bennett, James A. and Richard W. Sias, (2007), "Why do Anomalies Survive? The Idiosyncratic Risk of Arbitrage Portfolios" (July 3, 2007). Available at SSRN: http://ssrn.com/abstract=728585.

Brown, Stephen J., and Toshiyuki Otsuki, 1993, "Risk premia in Pacific-Basin capital markets," Pacific-Basin Finance Journal 1, 235-261.

Cavaglia, Stefano, Christopher. Brightman, and Michael. Aked, 2000, "The increasing importance of industry factors," Financial Analysts Journal 56, 41-54.

Choi, Jongmoo Jay, Takato Hiraki, and Nobuya Takezawa, 1998, "Is foreign exchange risk priced in Japan?” Journal of Financial and Quantitative Analysis 33, 361-382.

Chordia, Tarun, Asani Sarka, and Avanidhar Subramanyam, 2005, “An empirical analysis of stock and bond market liquidity," Review of Financial Studies 18, 85-129.

Dumas, Bernard, and Bruno Solnik, 1995, "The world price of foreign exchange risk," Journal of Finance 50, 445-477.

Elton, Edwin J., and Martin J. Gruber, 1995, Modern Portfolio Theory and Investment Analysis, Fifth Edition, ( Wiley \& Sons Inc.: New York, NY).

Fama, Eugene R., and Kenneth R. French, 1992, “The cross-section of expected stock returns,” Journal of Finance 47, 427-465.

Fama, Eugene R., and Kenneth R. French, 1993, "Common risk factors in the returns on stocks and bonds," Journal of Financial Economics 33, 3-56. 
Ferson, Wayne E., and Campbell R. Harvey, 1993, "The risk predictability of international equity returns," Review of Financial Studies 6, 527-566.

Goetzmann, William N., Lingfen Li, and K. Geert Rouwenhorst, 2005, "Long-term global market correlations,” Journal of Business 78, 1-38.

Goyal, Amit, and Pedro Santa-Clara, 2003, "Idiosyncratic risk matters!" Journal of Finance 58, 975-1008.

Guo, Hui, and Robert Savickas, 2006, "Idiosyncratic volatility, stock market volatility, and expected stock returns," Journal of Business and Economic Statistics 24, 43-56.

Heston, Steven L., and K. Geert Rouwenhorst, 1994, "Does industrial structure explain the benefits of international diversification?” Journal of Financial Economics 36, 3-28.

Malkiel, Burton G., and Yexiao Xu, 1997, “Risk and Return Revisited,” Journal of Portfolio Management 23 (Spring 1997), 9-34.

McElroy, Marjorie B., and Edwin Burmeister, 1988, “Arbitrage Pricing Theory as a Restricted Non-linear Regression Model: ITNLSUR Estimates,” Journal of Business and Economic Statistics 6, 29-42.

McElroy, Marjorie B., and Edwin Burmeister, 1991, “The Residual Market Factor, the APT, and Mean Variance Efficiency,” Review of Quantitative Finance and Accounting 1, 27-49.

Roll, Richard, 1992, "Industrial structure and the comparative behavior of international stock market indices," Journal of Finance 46, 3-42. 
White, Halbert, 1980, “A Heteroscedasticity-Consistent Covariance Matrix Estimator and a Direct Test for Heteroscedasticity," Econometrica 48, 817-838. 


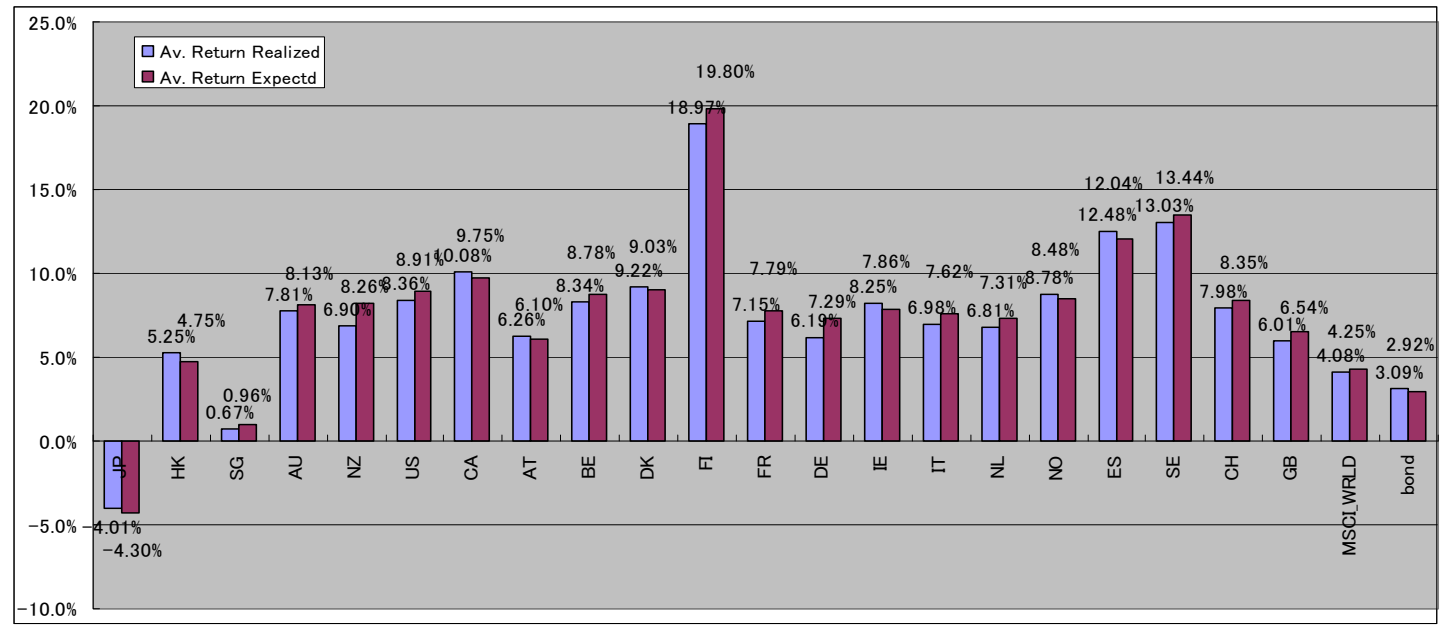

Figure 1. Comparison between average excess returns realized and average risk premia, April 1994

through December 2004. The figure depicts the average relationship between the expected excess

returns and the realized excess returns, both annualized. The risk premia are computed from the benchmark model for each of the 21 country indices and the two global market indices for equity and bond markets. 
Table I

Macro and Market Factors, Instruments, and County, Industry and Bond Indices

Factors and Instruments: The one-month U.S. Treasury-bill yield is applied to convert raw returns into excess returns for $m, b m$ and sus. Orthogonalized $m$ and $b m$ are used as factors while factor candidates, oil, sus teu and ljap, are converted into innovations through VAR procedure. VIX and FLOW are normalized measures of implied market volatility and equity flow, respectively. Inflation and yield-spread variables, ius, ysus, ysjap and yseu are the candidates of instrumental variables. All variables are measured on a monthly basis. MSCI 21 Country and Two World Market Indices: The 21-country index regime in the MSCI World Index starts from March 1994, corresponding to t-1 of the first month of our sample period April 1994 to December 2004. Only the member countries of the European Union, as of the end of December 2004 are included in the Euro group. The U.S. and Canada are formally not included in the Pacific-Basin country group. Excess returns on each country index are derived by subtracting one month T-bill yields after converting into U.S. dollar returns in each index. MSCI 23 Industry Indices: The 23-industry classes used in this study exclude the Semiconductor Industry, which has been in the MSCI_WRLD Index since May 2003. Raw returns on each industry index are first converted into U.S. dollars for raw r returns and then into excess returns by subtracting the one month T-bill yield. Citigroup Government Bond Indices: The U.S. and Japanese government bond market indices represent the two most important composites of the Citigroup World Government Bond Index (WGBI). Raw yen returns on the Japanese government bond index are first converted into U.S. dollar returns and then into excess returns by subtracting one-month U.S. T-bill yields. U.S. government bond index returns are converted into excess returns by subtracting the one-month U.S. T-bill yield. 
Table I (continued)

Panel A: Factors and Instruments

\begin{tabular}{llll}
\hline \multicolumn{1}{c}{ Factors/Instruments } & \multicolumn{1}{c}{ Notation } & & Description (before converting or orthogonalizing into innovation) \\
\cline { 1 - 1 } $\begin{array}{l}\text { World Equity Market Index } \\
\text { (MSCI_WRLD) }\end{array}$ & & MSCI Global Market Index excess returns in U.S. dollars \\
World Bond Market Index & bm (bond) & & Citigroup World Government Bond Index excess returns in U.S. dollars \\
Crude Oil Price & oil & & Log rates of changes in crude oil futures price \\
U.S. Small Stock Price & sus & & Log excess returns on the U.S. small stock index over MSCI_ \\
& & WRLD returns \\
Euro Short-term Interest & teu & Euro one-month returns \\
Yen-Dollar FOREX & ljap & Log rates of change in yen-dollar currency exchange rates \\
U.S. Inflation & ius & Log rates of changes in U.S. CPI \\
U.S. Term Structure & ysus & U.S. short- and long-term gov. bond yield spreads \\
Japanese Term Structure & ysjap & Japanese short- and long-term gov. bond yield spreads \\
Euro Term Structure & yseu & Euro short- and long-term bond yield spreads \\
Implied Volatility & VIX & Chicago Board Options Exchanges (CBOE) implied index option \\
& & volatility \\
Equity Flows & FLOW & Tokyo Stock Exchange net equity flow among the three investor \\
\end{tabular}


Table 1 (continued)

Panel B: MSCI 21 Country and Two World Market Indices

\begin{tabular}{lrrrrr}
\hline $\begin{array}{l}\text { Country/Market } \\
\text { Name }\end{array}$ & $\begin{array}{r}\text { Country } \\
\text { Symbol }\end{array}$ & $\begin{array}{r}\text { Ex .Ret. } \\
\text { Symbol }\end{array}$ & $\begin{array}{c}\text { EURO } \\
\text { I.D. }\end{array}$ & $\begin{array}{r}\text { Pacific-Basin } \\
\text { I.D. }\end{array}$ \\
\hline JAPAN & JP & R1 & 0 & 1 \\
HONG KONG & HK & R2 & 0 & 1 \\
SINGAPORE & SG & R3 & 0 & 1 \\
AUSTRALIA & AU & R4 & 0 & 1 \\
NEW ZEALAND & NZ & R5 & 0 & 1 \\
USA & US & R6 & 0 & 0 \\
CANADA & CA & R7 & 0 & 0 \\
AUSTRIA & AT & R8 & 1 & 0 \\
BELGIUM & BE & R9 & 1 & 0 \\
DENMARK & DK & R10 & 0 & 0 \\
FINLAND & FI & R11 & 1 & 0 \\
FRANCE & FR & R12 & 1 & 0 \\
GERMANY & DE & R13 & 1 & 0 \\
IRELAND & IE & R14 & 1 & 0 \\
ITALY & IT & R15 & 1 & 0 \\
NETHERLANDS & NL & R16 & 1 & 0 \\
NORWAY & NO & R17 & 0 & 0 \\
SPAIN & ES & R18 & 1 & 0 \\
SWEDEN & SE & R19 & 0 & 0 \\
SWITZERLAND & CH & R20 & 0 & 0 \\
UNITED KINGDOM & GB & R21 & 0 & 0 \\
\hline MSCI_WRLD & & R22 & & \\
bond & & R23 & & \\
\hline & & & &
\end{tabular}


(Table I continued)

Panel C: MSCI 23 Industry Indices

\begin{tabular}{lr}
\hline \multicolumn{1}{c}{ Industry Name } & $\begin{array}{r}\text { Ex. Ret. } \\
\text { Symbol }\end{array}$ \\
\hline Energy & R1 \\
Materials & R2 \\
Capital Goods & R3 \\
Commercial Services \& Supplies & R4 \\
Transportation & R5 \\
Automobiles \& Components & R6 \\
Consumer Durables \& Apparel & R7 \\
Hotels, Restaurants \& Leisure & R8 \\
Media & R9 \\
Retailing & R10 \\
Food \& Staples Retailing & R11 \\
Food, Beverage \& Tobacco & R12 \\
Household \& Personal Products & R13 \\
Health Care Equipment \& Services & R14 \\
Pharmaceuticals \& Biotechnology & R15 \\
Banks & R16 \\
Diversified Financials & R17 \\
Insurance & R18 \\
Real Estate & R19 \\
Software \& Services & R20 \\
Technology Hardware \& Equipment & R21 \\
Telecommunication Services & R22 \\
Utilities & R23 \\
\hline
\end{tabular}

Panel D: Citigroup Government Bond Indices

\begin{tabular}{lc}
\hline \multicolumn{1}{c}{ Index Name } & Description \\
\hline WGBI-Japan & Citigroup Japanese Government Bond Index excess returns in U.S. dollars \\
WGBI-U.S. & Bond Index excess returns in U.S. dollars \\
\hline
\end{tabular}




\section{Table II}

\section{Correlation Matrix of Country Index Returns: A Comparison between the First and the Second Sub-sample Period}

Each cell shows the correlation of monthly market index returns, converted into dollars, between two selected country indices. The entire sample period from April 1994 to December 2004 is almost evenly divided sub-periods at the end of 1999. Panel A (B) gives the result for the first (second) sub-period. All notations of the 21 coutry and 2 world market are Table I. A.

Panel A: First Sub-period: 1994.04-1999.12

\begin{tabular}{|c|c|c|c|c|c|c|c|c|c|c|c|c|c|c|c|c|c|c|c|c|c|c|}
\hline & & & & & & & & & & & & & & & & & & & & & & (MSCI_WRLD) \\
\hline JP & $\begin{array}{l}\text { JP } \\
1.0000\end{array}$ & HK & SG & $\mathrm{AU}$ & $\mathrm{NZ}$ & US & $\mathrm{CA}$ & AT & $\mathrm{BE}$ & DK & FI & FR & $\mathrm{DE}$ & IE & IT & $\mathrm{NL}$ & NO & ES & SE & $\mathrm{CH}$ & GB & $\mathrm{m} \quad \mathrm{bm}$ (Bond) \\
\hline $\mathrm{HK}$ & 0.4101 & 1.0000 & & & & & & & & & & & & & & & & & & & & \\
\hline SG & 0.4496 & 0.7941 & 1.0000 & & & & & & & & & & & & & & & & & & & \\
\hline $\mathrm{AU}$ & 0.5655 & 0.6146 & 0.5731 & 1.0000 & & & & & & & & & & & & & & & & & & \\
\hline $\mathrm{NZ}$ & 0.4445 & 0.4603 & 0.5484 & 0.6361 & 1.0000 & & & & & & & & & & & & & & & & & \\
\hline US & 0.3736 & 0.5874 & 0.5705 & 0.6065 & 0.4703 & 1.0000 & & & & & & & & & & & & & & & & \\
\hline CA & 0.3964 & 0.6354 & 0.6284 & 0.6546 & 0.5610 & 0.7899 & 1.0000 & & & & & & & & & & & & & & & \\
\hline AT & 0.2838 & 0.3500 & 0.2707 & 0.3325 & 0.4028 & 0.3539 & 0.4805 & 1.0000 & & & & & & & & & & & & & & \\
\hline $\mathrm{BE}$ & 0.2464 & 0.1291 & 0.1148 & 0.2903 & 0.3199 & 0.4767 & 0.3144 & 0.5103 & 1.0000 & & & & & & & & & & & & & \\
\hline DK & 0.1941 & 0.3112 & 0.2843 & 0.3125 & 0.3509 & 0.3743 & 0.4620 & 0.5323 & 0.5380 & 1.0000 & & & & & & & & & & & & \\
\hline FI & 0.3659 & 0.3418 & 0.3877 & 0.4853 & 0.4140 & 0.5838 & 0.5656 & 0.3822 & 0.4060 & 0.3791 & 1.0000 & & & & & & & & & & & \\
\hline FR & 0.3946 & 0.3782 & 0.3970 & 0.4512 & 0.4458 & 0.5533 & 0.5828 & 0.4636 & 0.6870 & 0.5667 & 0.4835 & 1.0000 & & & & & & & & & & \\
\hline DE & 0.2847 & 0.3781 & 0.3858 & 0.5420 & 0.4664 & 0.6165 & 0.5990 & 0.5791 & 0.6677 & 0.6375 & 0.6222 & 0.7152 & 1.0000 & & & & & & & & & \\
\hline IT & 0.1952 & 0.1211 & 0.2074 & 0.3363 & 0.2932 & 0.4370 & 0.3621 & 0.3558 & 0.5320 & 0.5394 & 0.3976 & 0.5727 & 0.4690 & 0.3920 & 1.0000 & & & & & & & \\
\hline NL & 0.4139 & 0.4378 & 4158 & 0.4564 & 0.5174 & 0.5930 & 0.5528 & 0.6711 & 0.7049 & 0.6275 & 0.5271 & 0.7127 & 0.7690 & 0.6743 & 0.4942 & 1.0000 & & & & & & \\
\hline NO & 0.3375 & 0.3665 & 4348 & 0.5371 & 0.5782 & 0.4778 & 0.6362 & 0.4525 & 0.3418 & 0.5150 & 0.5006 & 0.5195 & 0.4807 & 0.4839 & 0.4362 & 0.4799 & 1.0000 & & & & & \\
\hline ES & 0.3123 & 0.3992 & 4360 & 0.5568 & 0.4843 & 0.5674 & 0.5109 & 0.4312 & 0.5501 & 0.5374 & 0.4558 & 0.6483 & 0.5590 & 0.4891 & 0.6024 & 0.5713 & 0.5518 & 1.0000 & & & & \\
\hline SE & 0.3723 & 0.3802 & 0.4679 & 0.5241 & 0.5631 & 0.5569 & 0.5933 & 0.3932 & 0.3970 & 0.4791 & 0.7042 & 0.6316 & 0.7124 & 0.4442 & 0.4297 & 0.6735 & 0.5795 & 0.6103 & 1.0000 & & & \\
\hline CH & 0.3563 & 0.2726 & 0.2788 & 0.2982 & 0.4825 & 0.4453 & 0.4004 & 0.5371 & 0.5164 & 0.4931 & 0.2822 & 0.5339 & 0.5240 & 0.4385 & 0.3144 & 0.6392 & 0.3886 & 0.5570 & 0.4733 & 1.0000 & & \\
\hline & 0.4272 & 0.4935 & 0.4335 & 0.6012 & 0.5019 & 0.5739 & 0.5719 & 0.5637 & 0.5481 & 0.5219 & 0.5052 & 0.6673 & 0.6145 & 0.7046 & 0.4131 & 0.7640 & 0.4779 & 0.5825 & 0.5617 & 0.4828 & 1.0000 & \\
\hline m (MSCI_WRLD) & 0.6602 & 0.6129 & 0.6365 & 0.7282 & 0.5991 & 0.8957 & 0.8016 & 0.5153 & 0.5927 & 0.5111 & 0.6434 & 0.7293 & 0.7340 & 0.6417 & 0.5174 & 0.7601 & 0.5735 & 0.6787 & 0.6815 & 0.5902 & 0.7380 & 1.0000 \\
\hline bm (bond) & 0.2035 & 0.1509 & 0.0105 & -0.0412 & 0.0797 & 0.0111 & 0.0165 & 0.0606 & 0.2528 & 0.1790 & 0.0306 & 0.0915 & -0.0068 & 0.1641 & -0.1520 & 0.1667 & 0.0466 & -0.0239 & -0.0824 & 0.1670 & 0.1862 & 0.0795 \\
\hline
\end{tabular}


Table II (continued)

Panel B: Second Sub-period: 2000.01-2004.12

\begin{tabular}{|c|c|c|c|c|c|c|c|c|c|c|c|c|c|c|c|c|c|c|c|c|c|c|}
\hline & & & & & & & & & & & & & & & & & & & & & & (MSCI_WRLD) \\
\hline JP & $\begin{array}{l}\text { JP } \\
1.0000\end{array}$ & $\mathrm{HK}$ & SG & $\mathrm{AU}$ & $\mathrm{NZ}$ & US & $\mathrm{CA}$ & AT & $\mathrm{BE}$ & DK & FI & FR & $\mathrm{DE}$ & $\mathrm{IE}$ & IT & NL & NO & ES & SE & $\mathrm{CH}$ & GB & $\mathrm{m} \quad \mathrm{bm}$ (Bond) \\
\hline HK & 0.4224 & 1.0000 & & & & & & & & & & & & & & & & & & & & \\
\hline SG & 0.3138 & 0.6372 & 1.0000 & & & & & & & & & & & & & & & & & & & \\
\hline $\mathrm{AU}$ & 0.5500 & 0.5631 & 0.6365 & 1.0000 & & & & & & & & & & & & & & & & & & \\
\hline $\mathrm{NZ}$ & 0.4092 & 0.4605 & 0.5801 & 0.7080 & 1.0000 & & & & & & & & & & & & & & & & & \\
\hline US & 0.4934 & 0.6011 & 0.5654 & 0.6760 & 0.4834 & 1.0000 & & & & & & & & & & & & & & & & \\
\hline $\mathrm{CA}$ & 0.5472 & 0.6602 & 0.4997 & 0.7089 & 0.5096 & 0.7982 & 1.0000 & & & & & & & & & & & & & & & \\
\hline AT & 0.3794 & 0.4429 & 0.3972 & 0.4505 & 0.5535 & 0.3842 & 0.4046 & 1.0000 & & & & & & & & & & & & & & \\
\hline $\mathrm{BE}$ & 0.2493 & 0.5056 & 0.5264 & 0.5586 & 0.4814 & 0.5865 & 0.4780 & 0.7146 & 1.0000 & & & & & & & & & & & & & \\
\hline DK & 0.4126 & 0.5128 & 0.3080 & 0.5615 & 0.4300 & 0.7411 & 0.6900 & 0.5286 & 0.6558 & 1.0000 & & & & & & & & & & & & \\
\hline FI & 0.2297 & 0.3409 & 0.2014 & 0.4701 & 0.3334 & 0.5916 & 0.5005 & 0.0647 & 0.2658 & 0.4045 & 1.0000 & & & & & & & & & & & \\
\hline FR & 0.3602 & 0.5746 & 0.4494 & 0.6775 & 0.5141 & 0.7804 & 0.7077 & 0.5304 & 0.7738 & 0.7326 & 0.6278 & 1.0000 & & & & & & & & & & \\
\hline DE & 0.3065 & 0.5858 & 0.4771 & 0.6410 & 0.4674 & 0.7784 & 0.6403 & 0.5192 & 0.7350 & 0.7091 & 0.5339 & 0.9335 & 1.0000 & & & & & & & & & \\
\hline IE & 0.4219 & 0.4924 & 0.3980 & 0.6101 & 0.4394 & 0.6979 & 0.4806 & 0.5151 & 0.6571 & 0.6470 & 0.3836 & 0.6789 & 0.7341 & 1.0000 & & & & & & & & \\
\hline IT & 0.3170 & 0.5059 & 0.3834 & 0.5777 & 0.4839 & 0.5989 & 0.6084 & 0.5195 & 0.6747 & 0.5945 & 0.5060 & 0.8704 & 0.8256 & 0.5423 & 1.0000 & & & & & & & \\
\hline $\mathrm{NL}$ & 0.4109 & 0.5685 & 0.5235 & 0.6868 & 0.4973 & 0.7856 & 0.6480 & 0.5470 & 0.8223 & 0.7237 & 0.5129 & 0.9379 & 0.8994 & 0.7333 & 0.8250 & 1.0000 & & & & & & \\
\hline NO & 0.4614 & 0.5984 & 0.5151 & 0.7214 & 0.4659 & 0.7422 & 0.6662 & 0.5891 & 0.7980 & 0.7504 & 0.4584 & 0.8264 & 0.7985 & 0.6507 & 0.7188 & 0.8554 & 1.0000 & & & & & \\
\hline ES & 0.3709 & 0.5885 & 0.3996 & 0.6654 & 0.5117 & 0.7296 & 0.6565 & 0.5539 & 0.6785 & 0.6679 & 0.4687 & 0.8675 & 0.8633 & 0.7286 & 0.7849 & 0.8339 & 0.7285 & 1.0000 & & & & \\
\hline SE & 0.3245 & 0.6004 & 0.4147 & 0.6493 & 0.4394 & 0.7513 & 0.7113 & 0.3388 & 0.5340 & 0.6735 & 0.6369 & 0.8587 & 0.8627 & 0.5862 & 0.7787 & 0.7759 & 0.7079 & 0.8021 & 1.0000 & & & \\
\hline $\mathrm{CH}$ & 0.4061 & 0.5004 & 0.4028 & 0.5826 & 0.4725 & 0.6456 & 0.5435 & 0.6145 & 0.8123 & 0.6676 & 0.3883 & 0.7890 & 0.7089 & 0.6431 & 0.6701 & 0.8316 & 0.7495 & 0.6496 & 0.5712 & 1.0000 & & \\
\hline & 0.4206 & 0.5896 & 0.5518 & 0.6360 & 0.5012 & 0.8308 & 0.6463 & 0.5901 & 0.7956 & 0.7097 & 0.5433 & 0.8576 & 0.8057 & 0.7196 & 0.6832 & 0.8413 & 0.8193 & 0.7794 & 0.6711 & 0.8084 & 1.0000 & \\
\hline $\mathrm{m}$ (MSCI WRLD) & 0.5806 & 0.6651 & 0.5869 & 0.7577 & 0.5556 & 0.9680 & 0.8322 & 0.5006 & 0.6858 & 0.7846 & 0.6118 & 0.8809 & 0.8578 & 0.7484 & 0.7287 & 0.8778 & 0.8301 & 0.8196 & 0.8167 & 0.7450 & 0.8897 & 1.0000 \\
\hline bm (bond) & 0.2944 & 0.1247 & 0.0216 & 0.2706 & 0.3677 & -0.0103 & 0.1826 & 0.4879 & 0.3480 & 0.2411 & 0.0108 & 0.1645 & 0.0387 & 0.2081 & 0.2521 & 0.1324 & 0.1640 & 0.1922 & 0.0168 & 0.3514 & 0.2501 & 0.1118 \\
\hline
\end{tabular}




\section{Table III}

\section{Iterated Non-linear SUR (ITNLSUR) System Estimation of Equations for Global Equity Risk Premia}

\section{and Factor Risk Exposures, April 1994 - December 2004, with 21 Country Indices}

The benchmark model specification includes the energy price (oil), U.S. small-firm stock (sus), Euro-global interest rate (teu), yen/dollar currency exchange rate (ljap), and the two residual markets $(m$ and $\mathrm{bm}$ ) as factors and the Japanese yield spread (ysjap), U.S. yield spread (ysus), Euro yield spread (yseu), and VIX as instrumental variables. All factors and instruments are explained in Table 1 (panel A). It shows the VAR results for factor innovations based on equation (4). Panel B shows non-linear estimates of $\alpha$ coefficients based on equation (3) to determine risk premia. Panel C shows asset return processes for the 21 country indices and the MSCI_WRLD and bond, global equity, and bond market indices, based on equations (A1) through (A3). The degree of freedom is parenthesized.

Panel A: Global Factor Innovations: $\phi$ Estimates

\begin{tabular}{|c|c|c|c|c|c|c|c|c|c|}
\hline & const. & ysus & ysjap & yseu & VIX & oil & sus & teu & ljap \\
\hline $\begin{array}{l}\text { oil } \\
\qquad \text { (t-value) }\end{array}$ & $\begin{array}{r}-0.00552 \\
(-0.08)\end{array}$ & $\begin{array}{l}0.01620 \\
\quad(2.10)^{* *}\end{array}$ & $\begin{array}{c}0.04747 \\
\quad(1.77)^{*}\end{array}$ & $\begin{array}{r}-0.02293 \\
(-1.23)\end{array}$ & $\begin{array}{r}-0.00005 \\
(-0.03)\end{array}$ & $\begin{array}{l}-0.22852 \\
\quad(-3.25)^{* * *}\end{array}$ & $\begin{array}{l}-0.34980 \\
\quad(-2.07)^{* *}\end{array}$ & $\begin{array}{r}-14.37289 \\
(-1.25)\end{array}$ & $\begin{array}{l}0.37598 \\
\quad(2.12)^{* *}\end{array}$ \\
\hline $\begin{array}{l}\text { sus } \\
\qquad \text { (t-value) }\end{array}$ & $\begin{array}{c}-0.05371 \\
\quad(-2.03)^{* *}\end{array}$ & $\begin{array}{r}0.00444 \\
(1.45)\end{array}$ & $\begin{array}{r}-0.00729 \\
(-0.68)\end{array}$ & $\begin{array}{r}0.00713 \\
(0.96)\end{array}$ & $\begin{array}{r}0.00064 \\
(1.05)\end{array}$ & $\begin{array}{c}-0.05495 \\
\quad(-2.03)^{* *}\end{array}$ & $\begin{array}{r}-0.01457 \\
(-0.22)\end{array}$ & $\begin{array}{l}11.02744 \\
\quad(2.50)^{* * *}\end{array}$ & $\begin{array}{r}0.10388 \\
(1.53)\end{array}$ \\
\hline $\begin{array}{l}\text { teu } \\
\qquad \text { (t-value) }\end{array}$ & $\begin{array}{r}0.00010 \\
(0.97)\end{array}$ & $\begin{array}{c}-0.00002 \\
(-1.79)^{*}\end{array}$ & $\begin{array}{r}0.00003 \\
(0.88)\end{array}$ & $\begin{array}{r}-0.00001 \\
(-0.45)\end{array}$ & $\begin{array}{r}0.00000 \\
(0.32)\end{array}$ & $\begin{array}{r}-0.00006 \\
(-0.57)\end{array}$ & $\begin{array}{r}0.00009 \\
(0.34)\end{array}$ & $\begin{array}{l}0.95425 \\
\quad(51.67)^{* * *}\end{array}$ & $\begin{array}{r}-0.00012 \\
(-0.43)\end{array}$ \\
\hline $\begin{array}{l}\text { ljap } \\
\text { (t-value) }\end{array}$ & $\begin{array}{r}0.00360 \\
(0.15)\end{array}$ & $\begin{array}{r}-0.00314 \\
(-1.06)\end{array}$ & $\begin{array}{r}0.00955 \\
(0.98)\end{array}$ & $\begin{array}{r}-0.00325 \\
(-0.48)\end{array}$ & $\begin{array}{r}-0.00015 \\
(-0.26)\end{array}$ & $\begin{array}{r}-0.02554 \\
(-1.28)\end{array}$ & $\begin{array}{r}0.02897 \\
(0.61)\end{array}$ & $\begin{array}{r}-1.21185 \\
(-0.38)\end{array}$ & $\begin{array}{r}-0.01255 \\
(-0.25)\end{array}$ \\
\hline
\end{tabular}


Panel B: Risk Premia Determination Process: $\alpha$ Estimate

\begin{tabular}{|c|c|c|c|c|c|c|c|}
\hline & oil & sus & teu & ljap & $m$ & $\mathrm{bm}$ & $\left.\chi^{2} \quad 6\right)$ \\
\hline $\begin{array}{l}\text { const. } \\
\text { (tvalue) }\end{array}$ & $\begin{array}{c}0.24342 \\
(1.71)^{*}\end{array}$ & $\begin{array}{r}-0.08628 \\
(-2.18)\end{array}$ & $\begin{array}{r}0.00046 \\
(1.62)\end{array}$ & $\begin{array}{r}-0.12387 \\
(-2.92)^{* * *}\end{array}$ & $\begin{array}{r}-0.06457 \\
(-1.70)\end{array}$ * & $\begin{array}{c}0.08817 \\
(2.43)^{* *}\end{array}$ & $33.38^{* * *}$ \\
\hline $\begin{array}{l}\text { ysus } \\
\qquad \text { (tvalue) }\end{array}$ & $\begin{array}{c}0.03321 \\
\quad(1.72)^{*}\end{array}$ & $\begin{array}{r}0.00454 \\
(0.84)\end{array}$ & $\begin{array}{l}-0.00010 \\
(-2.62)^{* * *}\end{array}$ & $\begin{array}{r}0.00368 \\
(0.64)\end{array}$ & $\begin{array}{r}-0.00114 \\
(-0.22)\end{array}$ & $\begin{array}{l}0.01041 \\
\quad(2.11)^{* *}\end{array}$ & $37.34^{* * *}$ \\
\hline $\begin{array}{l}\text { ysjap } \\
\qquad \text { (tvalue) }\end{array}$ & $\begin{array}{r}-0.11837 \\
(-1.88)\end{array} *$ & $\begin{array}{r}0.02893 \\
(1.65)\end{array}$ & $\begin{array}{r}-0.00041 \\
(-3.28)^{* * *}\end{array}$ & $\begin{array}{l}0.05544 \\
\quad(2.98)^{* * *}\end{array}$ & $\begin{array}{r}0.00693 \\
(0.39)\end{array}$ & $\begin{array}{r}-0.02214 \\
(-1.36)\end{array}$ & $60.62^{* * *}$ \\
\hline $\begin{array}{l}\text { yseu } \\
\text { (tvalue) }\end{array}$ & $\begin{array}{r}-0.00690 \\
(-0.17)\end{array}$ & $\begin{array}{r}0.00634 \\
(0.55)\end{array}$ & $\begin{array}{l}0.00030 \\
(3.66)^{* * *}\end{array}$ & $\begin{array}{r}-0.02398 \\
(-1.96)^{*}\end{array}$ & $\begin{array}{r}0.00605 \\
(0.52)\end{array}$ & $\begin{array}{r}-0.00723 \\
(-0.68)\end{array}$ & $49.38^{* * *}$ \\
\hline $\begin{array}{l}\text { VIX } \\
\text { (tvalue) }\end{array}$ & $\begin{array}{r}-0.00602 \\
(-1.55)\end{array}$ & $\begin{array}{r}0.00122 \\
(1.13)\end{array}$ & $\begin{array}{r}-0.00001 \\
(-1.11)\end{array}$ & $\begin{array}{l}0.00381 \\
\quad(3.31)^{* * *}\end{array}$ & $\begin{array}{c}0.00249 \\
(2.47)^{\text {** }}\end{array}$ & $\begin{array}{r}-0.00268 \\
(-2.72)^{* * *}\end{array}$ & $31.49^{* * *}$ \\
\hline$\left.\chi^{2} \$\right)$ & $25.12^{* * *}$ & $16.36^{* * *}$ & $32.91^{* * *}$ & $23.68^{* * *}$ & $11.63^{* *}$ & $31.33^{* * *}$ & \\
\hline
\end{tabular}




\section{Table III (continued)}

\section{Panel C: Equity Risk Market Risk Exposures}

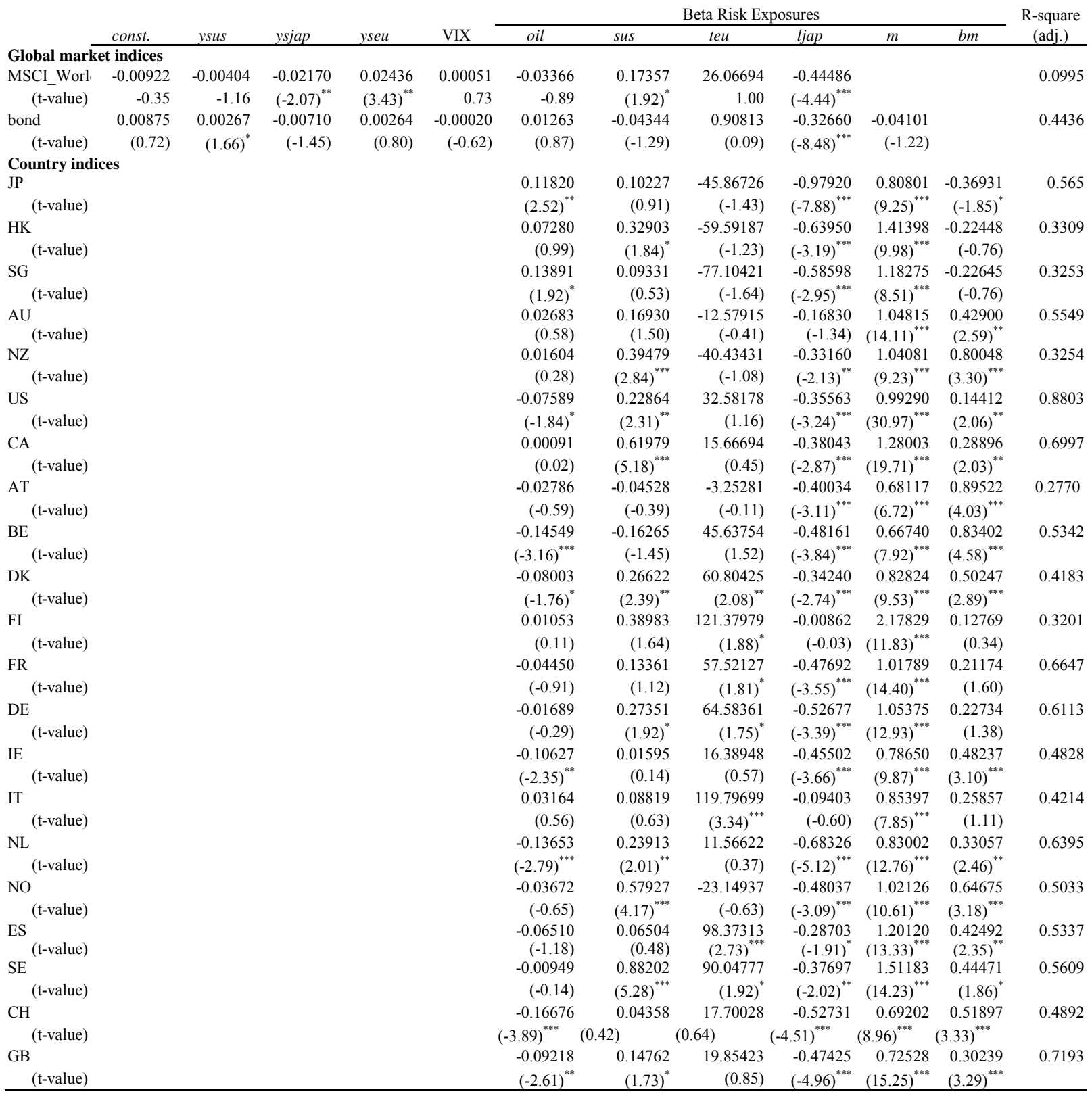

***Significant at the 1 percent level. 
**Significant at the 5 percent level.

*Significant at the 1 percent level. 
Table IV

\section{Risk Premia Estimation of the Benchmark Model with Four Different Asset Classes:}

\section{April 1994 - December 2004}

The benchmark model specification includes the energy price (oil), U.S. small-firm stock (sus), Euro-global interest rate (teu), yen/dollar currency exchange rate (ljap), and the two residual market returns $(\mathrm{m}$ and $\mathrm{bm})$ as factors and the Japanese yield spread (ysjap), U.S. yield spread (ysus), Euro yield spread (yseu) and VIX as instrumental variables. All factors and instruments are explained in panel A, Table 1. Each of the four panels shows estimates of $\alpha$ coefficients in matrix in equation (3). Panel A uses the 23 industry indices, panel B the nine Pacific-Basin market indices (five in panel A plus 4 including the U.S., Korea, Taiwan and the Philippines), panel $\mathrm{C}$ the 23 indices (= 21 country and two bond market indices) and panel D the 25 indices (= 23 industry and two bond market indices). t-statistics, parenthesized, are based on White's (1980) error adjustments for heteroscedasticity. Chi-square statistics, $\chi^{2}(\cdot)$, are for the null hypothesis that all $\alpha$ coefficients, including a constant, in a specified row or column are zero. The degree of freedom is parenthesized. 
Panel A: $\alpha$ Estimates for the 23 Industry Indices

\begin{tabular}{|c|c|c|c|c|c|c|c|}
\hline & oil & sus & teu & ljap & $m$ & $b m$ & $\left.\chi^{2} \quad 6\right)$ \\
\hline $\begin{array}{l}\text { const. } \\
\text { (‡value) }\end{array}$ & $\begin{array}{l}-0.29036 \\
(-3.16)^{* * *}\end{array}$ & $\begin{array}{r}0.01401 \\
(0.36)\end{array}$ & $\begin{array}{c}-0.00045 \\
(-1.67)^{*}\end{array}$ & $\begin{array}{l}0.11199 \\
(2.92)^{* * *}\end{array}$ & $\begin{array}{r}0.02512 \\
(1.21)\end{array}$ & $\begin{array}{c}0.02772 \\
(1.73)\end{array}$ * & $33.38^{* * *}$ \\
\hline $\begin{array}{l}\text { ysus } \\
\text { (tvalue) }\end{array}$ & $\begin{array}{r}0.00642 \\
(0.47)\end{array}$ & $\begin{array}{r}0.00777 \\
(1.38)\end{array}$ & $\begin{array}{r}-0.00011 \\
(-2.79)^{* * *}\end{array}$ & $\begin{array}{r}-0.00470 \\
(-0.81)\end{array}$ & $\begin{array}{r}-0.00155 \\
(-0.50)\end{array}$ & $\begin{array}{r}-0.00242 \\
(-1.00)\end{array}$ & $37.34^{* * *}$ \\
\hline $\begin{array}{l}\text { ysjap } \\
\quad \text { (tvalue) }\end{array}$ & $\begin{array}{l}0.10220 \\
(3.05)^{* * *}\end{array}$ & $\begin{array}{r}0.00798 \\
(0.55)\end{array}$ & $\begin{array}{r}0.00005 \\
(0.47)\end{array}$ & $\begin{array}{r}-0.02815 \\
(-2.03)\end{array}$ & $\begin{array}{r}-0.03444 \\
(-4.60)^{* * *}\end{array}$ & $\begin{array}{r}-0.00567 \\
(-0.98)\end{array}$ & $60.62^{* * *}$ \\
\hline $\begin{array}{l}\text { yseu } \\
\text { (tvalue) }\end{array}$ & $\begin{array}{r}0.00809 \\
(0.33)\end{array}$ & $\begin{array}{r}-0.01946 \\
(-1.88)\end{array}$ * & $\begin{array}{l}0.00014 \\
\quad(1.99)^{* *}\end{array}$ & $\begin{array}{r}0.00080 \\
(0.08)\end{array}$ & $\begin{array}{l}0.02465 \\
\quad(4.52)^{* * *}\end{array}$ & $\begin{array}{r}0.00297 \\
(0.70)\end{array}$ & $49.38^{* * *}$ \\
\hline $\begin{array}{l}\text { VIX } \\
\text { (tvalue) }\end{array}$ & $\begin{array}{l}0.00604 \\
(2.25)^{* *}\end{array}$ & $\begin{array}{r}-0.00069 \\
(-0.62)\end{array}$ & $\begin{array}{l}0.00002 \\
(2.50)^{* *}\end{array}$ & $\begin{array}{r}-0.00360 \\
(-3.20)^{* * *}\end{array}$ & $\begin{array}{r}-0.00063 \\
(-1.05)\end{array}$ & $\begin{array}{r}-0.00072 \\
(-1.52)\end{array}$ & $31.49^{* * *}$ \\
\hline$\left.\chi^{2} \$\right)$ & $20.94^{* * *}$ & 5.18 & $40.73^{* * *}$ & $21.29^{* * *}$ & $37.55^{* * *}$ & $14.98^{* *}$ & \\
\hline
\end{tabular}


Table IV (continued)

Panel B: $\alpha$ Estimates for the 9 Pacific-Basin Country Indices

\begin{tabular}{|c|c|c|c|c|c|c|c|}
\hline & oil & sus & teu & ljap & $m$ & $b m$ & $\chi^{2}$ (6) \\
\hline \multirow{2}{*}{$\begin{array}{l}\text { const. } \\
\text { (tvalue) }\end{array}$} & -1.03744 & -0.30803 & 0.00002 & -0.23595 & -0.04018 & -0.00440 & \multirow[t]{2}{*}{$14.84^{* *}$} \\
\hline & $(-1.00)$ & $(-1.15)$ & $(0.04)$ & $(-1.61)$ & $(-0.50)$ & $(-0.08)$ & \\
\hline \multirow{2}{*}{$\begin{array}{l}\text { ysus } \\
\quad \text { (tvalue) }\end{array}$} & 0.07762 & -0.01827 & -0.00007 & 0.01694 & 0.00879 & -0.00038 & \multirow[t]{2}{*}{$16.91^{* * *}$} \\
\hline & $(0.73)$ & $(-0.67)$ & $(-1.29)$ & (1.13) & (1.08) & $(-0.07)$ & \\
\hline \multirow{2}{*}{$\begin{array}{l}\text { ysjap } \\
\quad(\text { tvalue })\end{array}$} & 0.10130 & 0.03150 & -0.00012 & 0.05991 & 0.00261 & 0.00161 & \multirow[t]{2}{*}{9.09} \\
\hline & $(0.44)$ & $(0.53)$ & $(-0.94)$ & $(1.79)^{*}$ & $(0.14)$ & $(0.13)$ & \\
\hline \multirow{2}{*}{$\begin{array}{l}\text { yseu } \\
\quad \text { (‡value) }\end{array}$} & 0.26164 & 0.09293 & 0.00020 & 0.01128 & 0.00040 & 0.00705 & \multirow[t]{2}{*}{$20.73^{* * *}$} \\
\hline & $(0.96)$ & $(1.31)$ & $(1.35)$ & $(0.29)$ & $(0.02)$ & $(0.49)$ & \\
\hline \multirow{2}{*}{$\begin{array}{l}\text { VIX } \\
\quad \text { (tvalue) }\end{array}$} & 0.01379 & 0.00595 & 0.00000 & 0.00479 & 0.00141 & -0.00029 & \multirow[t]{2}{*}{$12.46^{*}$} \\
\hline & $(0.70)$ & (1.17) & $(-0.06)$ & $(1.71)^{*}$ & $(0.92)$ & $(-0.28)$ & \\
\hline$\left.\chi^{2} \$\right)$ & $13.76^{* *}$ & $10.02^{*}$ & 6.02 & $11.38^{* *}$ & 7.53 & 2.69 & \\
\hline
\end{tabular}

Panel C. $\alpha$ Estimates for the 23 Indices Consisting of 21MSCI Country Indices and Two (U.S. and

Japanese) Bond Market Indices

\begin{tabular}{|c|c|c|c|c|c|c|c|}
\hline & oil & sus & teu & ljap & $m$ & $b m$ & $\left.\chi^{2} \quad 6\right)$ \\
\hline $\begin{array}{l}\text { const. } \\
\text { (tvalue) }\end{array}$ & $\begin{array}{r}0.17527 \\
(1.46)\end{array}$ & $\begin{array}{r}-0.27342 \\
(-3.79)^{* * *}\end{array}$ & $\begin{array}{r}0.00021 \\
(0.84)\end{array}$ & $\begin{array}{r}0.02337 \\
(0.89)\end{array}$ & $\begin{array}{r}0.04070 \\
(1.06)\end{array}$ & $\begin{array}{c}0.05472 \\
(2.60)\end{array}$ & $40.34^{* * *}$ \\
\hline $\begin{array}{l}\text { ysus } \\
\qquad \text { (tvalue) }\end{array}$ & $\begin{array}{l}0.02991 \\
\quad(2.15)^{* *}\end{array}$ & $\begin{array}{r}0.00108 \\
(0.13)\end{array}$ & $\begin{array}{r}-0.00010 \\
(-3.48)^{* * *}\end{array}$ & $\begin{array}{r}0.00143 \\
(0.43)\end{array}$ & $\begin{array}{r}0.00033 \\
(0.07)\end{array}$ & $\begin{array}{c}0.00416 \\
(1.71)^{*}\end{array}$ & $37.08^{* * *}$ \\
\hline $\begin{array}{l}\text { ysjap } \\
\text { (tvalue) }\end{array}$ & $\begin{array}{c}-0.08354 \\
(-1.69)^{*}\end{array}$ & $\begin{array}{l}0.09282 \\
\quad(3.12)^{* * *}\end{array}$ & $\begin{array}{c}-0.00029 \\
(-2.85)^{* * *}\end{array}$ & $\begin{array}{r}0.00198 \\
(0.19)\end{array}$ & $\begin{array}{c}-0.03052 \\
(-1.91)\end{array}$ & $\begin{array}{r}-0.01033 \\
(-1.18)\end{array}$ & $62.15^{* * *}$ \\
\hline $\begin{array}{l}\text { yseu } \\
\text { (tvalue) }\end{array}$ & $\begin{array}{r}-0.01461 \\
(-0.51)\end{array}$ & $\begin{array}{r}-0.00893 \\
(-0.52)\end{array}$ & $\begin{array}{l}0.00022 \\
\quad(3.70)^{* * *}\end{array}$ & $\begin{array}{r}-0.00399 \\
(-0.59)\end{array}$ & $\begin{array}{l}0.02129 \\
(2.29)^{* *}\end{array}$ & $\begin{array}{r}-0.00253 \\
(-0.50)\end{array}$ & $46.09^{* * *}$ \\
\hline $\begin{array}{l}\text { VIX } \\
\text { (tvalue) }\end{array}$ & $\begin{array}{r}-0.00404 \\
(-1.22)\end{array}$ & $\begin{array}{l}0.00777 \\
\quad(3.88)^{* * *}\end{array}$ & $\begin{array}{r}0.00000 \\
(0.54)\end{array}$ & $\begin{array}{r}-0.00128 \\
(-1.80)^{*}\end{array}$ & $\begin{array}{r}-0.00164 \\
(-1.54)\end{array}$ & $\begin{array}{r}-0.00173 \\
(-2.96)^{* * *}\end{array}$ & $42.82^{* * *}$ \\
\hline$\left.\chi^{2} \$\right)$ & $23.87^{* * *}$ & $47.92^{* * *}$ & $41.22^{* * *}$ & 7.23 & $16.66^{* * *}$ & $39.64^{* * *}$ & \\
\hline
\end{tabular}


Table IV (continued)

Panel D. $\alpha$ Estimates for the 25 Indices Consisting of 23MSCI Industry Indices and Two (U.S. and

$$
\text { Japanese) Bond Market Indices }
$$

\begin{tabular}{|c|c|c|c|c|c|c|c|}
\hline & oil & sus & teu & ljap & $m$ & $b m$ & $\left.\chi^{2} \quad 6\right)$ \\
\hline $\begin{array}{l}\text { onst. } \\
\text { (tvalue) }\end{array}$ & $\begin{array}{c}-0.30277 \\
(-3.78)^{\text {*** }}\end{array}$ & $\begin{array}{r}-0.02125 \\
(-0.68)\end{array}$ & $\begin{array}{c}-0.00044 \\
(-1.92)^{*}\end{array}$ & $\begin{array}{r}0.02321 \\
(1.09)\end{array}$ & $\begin{array}{r}0.03017 \\
(1.22)\end{array}$ & $\begin{array}{c}0.01982 \\
(1.78)\end{array}{ }^{*}$ & $31.64^{* * *}$ \\
\hline $\begin{array}{l}\text { ysus } \\
\qquad \text { (tvalue) }\end{array}$ & $\begin{array}{r}0.01234 \\
(1.05)\end{array}$ & $\begin{array}{l}0.01027 \\
\quad(2.28)^{* *}\end{array}$ & $\begin{array}{r}-0.00010 \\
(-2.97)^{* * *}\end{array}$ & $\begin{array}{r}-0.00383 \\
(-1.31)\end{array}$ & $\begin{array}{r}-0.00356 \\
(-0.97)\end{array}$ & $\begin{array}{r}0.00051 \\
(0.31)\end{array}$ & $32.95^{* * *}$ \\
\hline $\begin{array}{l}\text { ysjap } \\
\text { (Evalue) }\end{array}$ & $\begin{array}{r}0.08826 \\
(3.05)^{* * *}\end{array}$ & $\begin{array}{l}0.02530 \\
(2.20)^{* *}\end{array}$ & $\begin{array}{r}0.00003 \\
(0.41)\end{array}$ & $\begin{array}{r}0.00692 \\
(0.85)\end{array}$ & $\begin{array}{r}-0.03157 \\
(-3.54)^{* * *}\end{array}$ & $\begin{array}{r}0.00387 \\
(0.96)\end{array}$ & $44.00^{* * *}$ \\
\hline $\begin{array}{l}\text { yseu } \\
\text { (tvalue) }\end{array}$ & $\begin{array}{r}0.01262 \\
(0.59)\end{array}$ & $\begin{array}{r}-0.02757 \\
(-3.31)^{* * *}\end{array}$ & $\begin{array}{c}0.00012 \\
(1.96)^{*}\end{array}$ & $\begin{array}{r}-0.00594 \\
(-1.04)\end{array}$ & $\begin{array}{l}0.02386 \\
\quad(3.65)^{* * *}\end{array}$ & $\begin{array}{r}-0.00552 \\
(-1.85)^{*}\end{array}$ & $52.16^{* * *}$ \\
\hline $\begin{array}{l}\text { VIX } \\
\text { (tvalue) }\end{array}$ & $\begin{array}{l}0.00676 \\
\quad(2.84)^{* * *}\end{array}$ & $\begin{array}{r}0.00033 \\
(0.36)\end{array}$ & $\begin{array}{l}0.00002 \\
\quad(3.04)^{* * *}\end{array}$ & $\begin{array}{r}-0.00096 \\
(-1.63)\end{array}$ & $\begin{array}{r}-0.00067 \\
(-0.90)\end{array}$ & $\begin{array}{r}-0.00048 \\
(-1.45)\end{array}$ & $34.56^{* * *}$ \\
\hline$\left.\chi^{2} \$\right)$ & $22.4^{* * *}$ & $14.62^{* *}$ & $48.05^{* * *}$ & $10.81^{*}$ & $18.62^{* * *}$ & $34.61^{* * *}$ & \\
\hline
\end{tabular}

***Significant at the 1 percent level.

**Significant at the 5 percent level.

* Significant at the 1 percent level. 


\section{Table V}

\section{Decomposing Total Excess Return Variance of Country Indices into Variance-Covariance \\ Components: Entire Period (April 1994 to December 2004) and Two Sub-periods (April 1994 to}

\section{December 1999 and January 2000 to December 2004)}

Total variance and decomposed risk of global markets are aggregated without allocating any weight to each of the 21 component country indices. The result is based on the benchmark model specification whose parameter estimation is given in Table III. The total variance decomposition into four components is based on equation (7). The risk-premia-caused part of the variance is further decomposed into diagonal and off-diagonal sub-components based on equation (8). The factor innovation component of the variance is further decomposed into diagonal and off-diagonal sub-components based on equation (9). Residuals and factor-residual covariance parts of risk are also similarly decomposed into diagonal and off-diagonal sub-components. Each panel of this table includes similar risk decomposition in which total risk at each risk type is decomposed into Euro, non-Euro and "Cross" (total off-diagonal) contributions. All risks are measured are on a monthly basis. All percent figures show the percent contribution of each risk to the total risk $(100 \%)$. 


\begin{tabular}{|c|c|c|c|c|c|c|}
\hline \multirow{2}{*}{\multicolumn{4}{|c|}{ Panel A: Entire Period: April 1994 through December 2004}} & \multicolumn{3}{|c|}{ Percent } \\
\hline & & & & & & \\
\hline All 21 Country Indices & Diagonal & Off-diag. & Total & Diagonal & Off-diag. & Total \\
\hline Time-Varying Risk Premia & 0.006 & 0.054 & 0.060 & $0.64 \%$ & $6.13 \%$ & $6.76 \%$ \\
\hline $\operatorname{Cov}\left(E_{t-1}\left(R_{t}\right), R_{t}\right)$ & 0.011 & 0.112 & 0.124 & $1.29 \%$ & $12.74 \%$ & $14.03 \%$ \\
\hline $\operatorname{Var}\left(E_{t-1}\left(R_{t}\right)\right)$ & -0.006 & -0.058 & -0.064 & $-0.66 \%$ & $-6.61 \%$ & $-7.27 \%$ \\
\hline Factor Innovations & 0.045 & 0.710 & 0.755 & $5.08 \%$ & $80.63 \%$ & $85.71 \%$ \\
\hline Residuals & 0.040 & 0.042 & 0.082 & $4.56 \%$ & $4.79 \%$ & $9.35 \%$ \\
\hline Factor-Residual Cov & -0.009 & -0.007 & -0.016 & $-0.97 \%$ & $-0.85 \%$ & $-1.82 \%$ \\
\hline Total Variance & 0.082 & 0.798 & 0.880 & $9.31 \%$ & $90.69 \%$ & $100.00 \%$ \\
\hline Euro, Non-Euro and Cross & Euro & Non-Euro & Cross & Euro & Non-Euro & Cross \\
\hline Time-Varying Risk Premia & 0.019 & 0.013 & 0.027 & $2.17 \%$ & $1.51 \%$ & $3.08 \%$ \\
\hline $\operatorname{Cov}\left(E_{t-1}\left(R_{t}\right), R_{t}\right)$ & 0.039 & 0.028 & 0.056 & $4.43 \%$ & $3.19 \%$ & $6.42 \%$ \\
\hline $\operatorname{Var}\left(E_{t-1}\left(R_{t}\right)\right)$ & -0.020 & -0.015 & -0.029 & $-2.25 \%$ & $-1.68 \%$ & $-3.34 \%$ \\
\hline Factor Innovations & 0.134 & 0.262 & 0.358 & $15.21 \%$ & $29.81 \%$ & $40.70 \%$ \\
\hline Residuals & 0.040 & 0.034 & 0.009 & $4.49 \%$ & $3.82 \%$ & $1.04 \%$ \\
\hline Factor-Residual Cov & 0.007 & -0.026 & 0.003 & $0.75 \%$ & $-2.96 \%$ & $0.39 \%$ \\
\hline Total Variance & 0.199 & 0.283 & 0.398 & $22.61 \%$ & $32.18 \%$ & $45.21 \%$ \\
\hline
\end{tabular}


Table V (continued)

\begin{tabular}{|c|c|c|c|c|c|c|}
\hline \multicolumn{7}{|c|}{ Panel B: First Sub-period: April 1994 through December 1999} \\
\hline All 21 Country Indices & Diagonal & Off-diag. & Total & Diagonal & Off-diag. & Total \\
\hline Time-Varying Risk Premia & 0.005 & 0.002 & 0.007 & $0.72 \%$ & $0.23 \%$ & $0.95 \%$ \\
\hline $\operatorname{Cov}\left(E_{t-1}\left(R_{t}\right), R_{t}\right)$ & 0.010 & 0.003 & 0.013 & $1.44 \%$ & $0.46 \%$ & $1.91 \%$ \\
\hline $\operatorname{Var}\left(\mathrm{E}_{\mathrm{t}-1}\left(\mathrm{R}_{\mathrm{t}}\right)\right)$ & -0.005 & -0.002 & -0.007 & $-0.72 \%$ & $-0.23 \%$ & $-0.95 \%$ \\
\hline Factor Innovations & 0.033 & 0.460 & 0.493 & $4.60 \%$ & $65.16 \%$ & $69.76 \%$ \\
\hline Residuals & 0.039 & 0.078 & 0.117 & $5.50 \%$ & $11.04 \%$ & $16.55 \%$ \\
\hline Factor-Residual Cov & -0.003 & 0.093 & 0.090 & $-0.37 \%$ & $13.11 \%$ & $12.74 \%$ \\
\hline Total Variance & 0.074 & 0.632 & 0.706 & $10.46 \%$ & $89.54 \%$ & $100.00 \%$ \\
\hline Euro, Non-Euro and Cross & Euro & Non-Euro & Cross & Euro & Non-Euro & Cross \\
\hline Time-Varying Risk Premia & 0.011 & 0.006 & -0.010 & $1.52 \%$ & $0.89 \%$ & $-1.45 \%$ \\
\hline $\operatorname{Cov}\left(E_{t-1}\left(R_{t}\right), R_{t}\right)$ & 0.021 & 0.013 & -0.021 & $3.03 \%$ & $1.78 \%$ & $-2.91 \%$ \\
\hline $\operatorname{Var}\left(\mathrm{E}_{\mathrm{t}-1}\left(\mathrm{R}_{\mathrm{t}}\right)\right)$ & -0.011 & -0.006 & 0.010 & $-1.52 \%$ & $-0.89 \%$ & $1.45 \%$ \\
\hline Factor Innovations & 0.072 & 0.196 & 0.225 & $10.26 \%$ & $27.69 \%$ & $31.81 \%$ \\
\hline Residuals & 0.042 & 0.044 & 0.030 & $5.94 \%$ & $6.29 \%$ & $4.31 \%$ \\
\hline Factor-Residual Cov & 0.019 & 0.014 & 0.057 & $2.66 \%$ & $2.01 \%$ & $8.07 \%$ \\
\hline Total Variance & 0.144 & 0.260 & 0.302 & $20.38 \%$ & $36.89 \%$ & $42.73 \%$ \\
\hline \multicolumn{7}{|c|}{ Panel C: Second Sub-period: January 2000 through December 2004} \\
\hline All 21 Country Indices & Diagonal & Off-diag. & Total & Diagonal & Off-diag. & Total \\
\hline Time-Varying Risk Premia & 0.012 & 0.160 & 0.172 & $1.18 \%$ & $15.42 \%$ & $16.60 \%$ \\
\hline $\operatorname{Cov}\left(E_{t-1}\left(R_{t}\right), R_{t}\right)$ & 0.025 & 0.331 & 0.356 & $2.42 \%$ & $31.87 \%$ & $34.29 \%$ \\
\hline $\operatorname{Var}\left(\mathrm{E}_{\mathrm{t}-1}\left(\mathrm{R}_{\mathrm{t}}\right)\right)$ & -0.013 & -0.171 & -0.184 & $-1.24 \%$ & $-16.45 \%$ & $-17.69 \%$ \\
\hline Factor Innovations & 0.048 & 0.786 & 0.834 & $4.63 \%$ & $75.73 \%$ & $80.36 \%$ \\
\hline Residuals & 0.031 & 0.013 & 0.044 & $2.99 \%$ & $1.29 \%$ & $4.28 \%$ \\
\hline Factor-Residual Cov & -0.004 & -0.009 & -0.013 & $-0.38 \%$ & $-0.85 \%$ & $-1.24 \%$ \\
\hline Total Variance & 0.087 & 0.950 & 1.037 & $8.42 \%$ & $91.58 \%$ & $100.00 \%$ \\
\hline Euro, Non-Euro and Cross & Euro & Non-Euro & Cross & Euro & Non-Euro & Cross \\
\hline Time-Varying Risk Premia & 0.037 & 0.051 & 0.085 & $3.54 \%$ & $4.89 \%$ & $8.17 \%$ \\
\hline $\operatorname{Cov}\left(E_{t-1}\left(R_{t}\right), R_{t}\right)$ & 0.074 & 0.107 & 0.175 & $7.13 \%$ & $10.32 \%$ & $16.84 \%$ \\
\hline $\operatorname{Var}\left(\mathrm{E}_{\mathrm{t}-1}\left(\mathrm{R}_{\mathrm{t}}\right)\right)$ & -0.037 & -0.056 & -0.090 & $-3.59 \%$ & $-5.42 \%$ & $-8.67 \%$ \\
\hline Factor Innovations & 0.196 & 0.227 & 0.411 & $18.89 \%$ & $21.89 \%$ & $39.58 \%$ \\
\hline Residuals & 0.029 & 0.019 & -0.003 & $2.78 \%$ & $1.80 \%$ & $-0.30 \%$ \\
\hline Factor-Residual Cov & -0.010 & 0.003 & -0.006 & $-0.98 \%$ & $0.31 \%$ & $-0.56 \%$ \\
\hline Total Variance & 0.251 & 0.300 & 0.486 & $24.22 \%$ & $28.90 \%$ & $46.88 \%$ \\
\hline
\end{tabular}




\section{Table VI}

\section{Decomposing Total Excess Return Variance of Industry Indices into Variance-Covariance}

\section{Components: Entire Period (April 1994 to December 2004) and Two Sub-periods (April 1994 to}

December 1999 and January 2000 to December 2004)

Total variance and decomposed risk of global markets are aggregated without allocating any weight to each of the 23 composite industry indices. The result is for the benchmark model specification whose partial parameter estimation is given in Table IV (Panel A) for the entire period. The total variance decomposition into four components is based on equation (7). The risk-premia-caused part of the variance is further decomposed into diagonal and off-diagonal sub-components based on equation (8). The factor innovation component of the variance is further decomposed into diagonal and off-diagonal sub-components based on equation (9). Residuals and factor-residual covariance parts of risk are also similarly decomposed into diagonal and off-diagonal sub-components. All risks are measured on a monthly basis. All percent figures show the percent contribution of each risk to the total risk (100\%). 


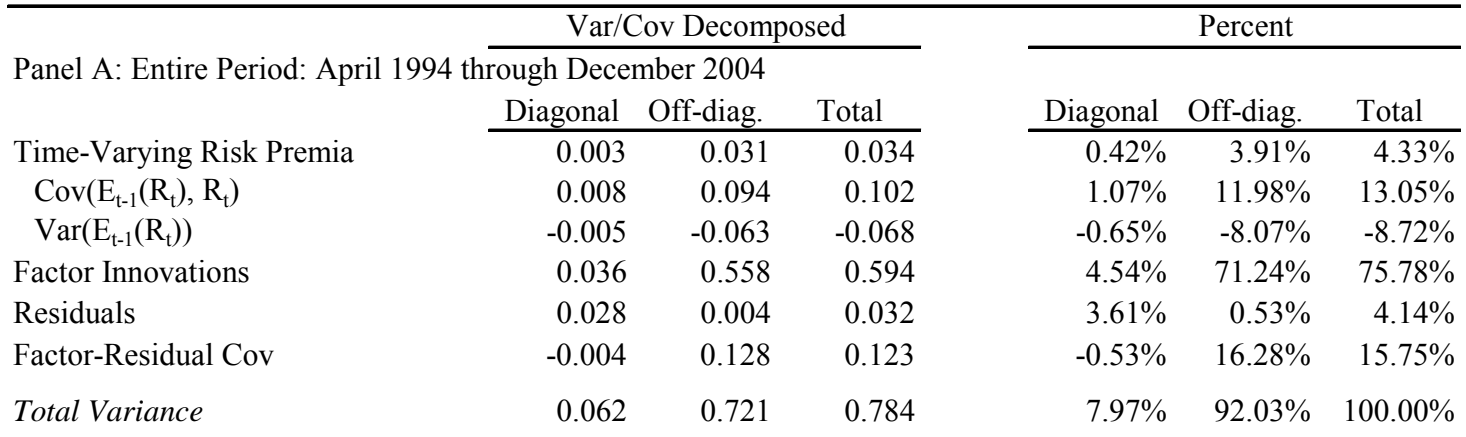

Panel B: First Sub-period: April 1994 through December 1999

\begin{tabular}{|c|c|c|c|c|c|c|}
\hline & Diagonal & Off-diag. & Total & Diagonal & Off-diag. & Total \\
\hline Time-Varying Risk Premia & 0.002 & 0.009 & 0.011 & $0.33 \%$ & $1.35 \%$ & $1.68 \%$ \\
\hline $\operatorname{Cov}\left(E_{t-1}\left(R_{t}\right), R_{t}\right)$ & 0.005 & 0.024 & 0.029 & $0.70 \%$ & $3.68 \%$ & $4.38 \%$ \\
\hline $\operatorname{Var}\left(\mathrm{E}_{\mathrm{t}-1}\left(\mathrm{R}_{\mathrm{t}}\right)\right)$ & -0.002 & -0.015 & -0.018 & $-0.37 \%$ & $-2.33 \%$ & $-2.70 \%$ \\
\hline Factor Innovations & 0.032 & 0.598 & 0.630 & $4.94 \%$ & $91.81 \%$ & $96.75 \%$ \\
\hline Residuals & 0.021 & -0.010 & 0.011 & $3.18 \%$ & $-1.49 \%$ & $1.68 \%$ \\
\hline Factor-Residual Cov & -0.003 & 0.003 & -0.001 & $-0.52 \%$ & $0.41 \%$ & $-0.11 \%$ \\
\hline Total Variance & 0.051 & 0.600 & 0.651 & $7.88 \%$ & $92.12 \%$ & $100.00 \%$ \\
\hline \multicolumn{7}{|c|}{ Panel C: Second Sub-period: January 2000 through December 2004} \\
\hline & Diagonal & Off-diag. & Total & Diagonal & Off-diag. & Total \\
\hline Time-Varying Risk Premia & 0.010 & 0.091 & 0.101 & $1.10 \%$ & $10.29 \%$ & $11.39 \%$ \\
\hline $\operatorname{Cov}\left(E_{t-1}\left(R_{t}\right), R_{t}\right)$ & 0.021 & 0.214 & 0.235 & $2.39 \%$ & $24.15 \%$ & $26.54 \%$ \\
\hline $\operatorname{Var}\left(\mathrm{E}_{\mathrm{t}-1}\left(\mathrm{R}_{\mathrm{t}}\right)\right)$ & -0.011 & -0.123 & -0.134 & $-1.29 \%$ & $-13.86 \%$ & $-15.15 \%$ \\
\hline Factor Innovations & 0.044 & 0.701 & 0.744 & $4.94 \%$ & $78.98 \%$ & $83.92 \%$ \\
\hline Residuals & 0.022 & 0.009 & 0.030 & $2.46 \%$ & $0.96 \%$ & $3.42 \%$ \\
\hline Factor-Residual Cov & -0.003 & 0.015 & 0.011 & $-0.38 \%$ & $1.66 \%$ & $1.28 \%$ \\
\hline Total Variance & 0.071 & 0.816 & 0.887 & $7.99 \%$ & $92.01 \%$ & $100.00 \%$ \\
\hline
\end{tabular}


Table VII

Average Excess Returns Realized and Average Risk Premia Predicted for 21 Country Indices and 2 Market Indices: April 1994 through December 2004, T = 129 Months

Monthly excess returns are annualized on a monthly compounding basis. t-values are computed on the monthly series of differences between realized and expected excess returns. All index names are given in Table I (A). Av. Ann. Ret. Realized = Average Realized Excess Return per Annum; Std. Dev. Ann. Ret. = Standard Deviation of Realized Excess Returns per Annum; Av. Ann. Ret. Expected = Average Expected Excess Return per Annum; Diff. (Ann.) = Average Difference between Realized Excess Returns and Expected Excess Returns per Annum; Diff. (Mon.) = Average Difference between Realized Excess Returns and Expected Excess Returns per Month. 


\begin{tabular}{|c|c|c|c|c|c|c|}
\hline Index & $\begin{array}{c}\text { Av. Ann. Ret. } \\
\text { Realized }\end{array}$ & $\begin{array}{l}\text { Std. Dev. } \\
\text { Ann. Ret. }\end{array}$ & $\begin{array}{l}\text { Av. Ann. Ret. } \\
\text { Expected }\end{array}$ & Diff. (Ann.) & Diff. (Mon.) & t-value \\
\hline JP & $-4.01 \%$ & $19.77 \%$ & $-4.30 \%$ & $0.29 \%$ & $0.02 \%$ & 0.05 \\
\hline HK & $5.25 \%$ & $28.07 \%$ & $4.75 \%$ & $0.50 \%$ & $0.04 \%$ & 0.06 \\
\hline SG & $0.67 \%$ & $27.20 \%$ & $0.96 \%$ & $-0.29 \%$ & $-0.02 \%$ & -0.03 \\
\hline AU & $7.81 \%$ & $17.22 \%$ & $8.13 \%$ & $-0.32 \%$ & $-0.03 \%$ & -0.06 \\
\hline $\mathrm{NZ}$ & $6.90 \%$ & $20.90 \%$ & $8.26 \%$ & $-1.36 \%$ & $-0.11 \%$ & -0.21 \\
\hline US & $8.36 \%$ & $14.78 \%$ & $8.91 \%$ & $-0.55 \%$ & $-0.05 \%$ & -0.12 \\
\hline CA & $10.08 \%$ & $18.77 \%$ & $9.75 \%$ & $0.32 \%$ & $0.03 \%$ & 0.06 \\
\hline AT & $6.26 \%$ & $17.52 \%$ & $6.10 \%$ & $0.17 \%$ & $0.01 \%$ & 0.03 \\
\hline $\mathrm{BE}$ & $8.34 \%$ & $17.29 \%$ & $8.78 \%$ & $-0.44 \%$ & $-0.04 \%$ & -0.08 \\
\hline DK & $9.22 \%$ & $17.19 \%$ & $9.03 \%$ & $0.19 \%$ & $0.02 \%$ & 0.04 \\
\hline FI & $18.97 \%$ & $35.40 \%$ & $19.80 \%$ & $-0.84 \%$ & $-0.07 \%$ & -0.08 \\
\hline FR & $7.15 \%$ & $18.05 \%$ & $7.79 \%$ & $-0.64 \%$ & $-0.05 \%$ & -0.12 \\
\hline DE & $6.19 \%$ & $21.69 \%$ & $7.29 \%$ & $-1.09 \%$ & $-0.09 \%$ & -0.16 \\
\hline IE & $8.25 \%$ & $17.55 \%$ & $7.86 \%$ & $0.39 \%$ & $0.03 \%$ & 0.07 \\
\hline IT & $6.98 \%$ & $21.03 \%$ & $7.62 \%$ & $-0.64 \%$ & $-0.05 \%$ & -0.10 \\
\hline NL & $6.81 \%$ & $18.27 \%$ & $7.31 \%$ & $-0.50 \%$ & $-0.04 \%$ & -0.09 \\
\hline NO & $8.78 \%$ & $22.04 \%$ & $8.48 \%$ & $0.30 \%$ & $0.03 \%$ & 0.04 \\
\hline ES & $12.48 \%$ & $20.40 \%$ & $12.04 \%$ & $0.44 \%$ & $0.04 \%$ & 0.07 \\
\hline SE & $13.03 \%$ & $25.14 \%$ & $13.44 \%$ & $-0.41 \%$ & $-0.03 \%$ & -0.05 \\
\hline $\mathrm{CH}$ & $7.98 \%$ & $16.32 \%$ & $8.35 \%$ & $-0.38 \%$ & $-0.03 \%$ & -0.08 \\
\hline GB & $6.01 \%$ & $13.26 \%$ & $6.54 \%$ & $-0.53 \%$ & $-0.04 \%$ & -0.13 \\
\hline MSCI_WF & $4.08 \%$ & $13.80 \%$ & $4.25 \%$ & $-0.17 \%$ & $-0.01 \%$ & -0.09 \\
\hline bond & $3.09 \%$ & $6.51 \%$ & $2.92 \%$ & $0.17 \%$ & $0.01 \%$ & 0.09 \\
\hline
\end{tabular}

\#No statistically significant differences are recorded in the total of 23 indices at any conventional level. 